\title{
Comparative genomics of the major fungal agents of human and animal Sporotrichosis: Sporothrix schenckii and Sporothrix brasiliensis
}

Marcus M Teixeira' ${ }^{1}$ Luiz GP de Almeida², Paula Kubitschek-Barreira ${ }^{3}$, Fernanda L Alves ${ }^{4,5}$, Érika S Kioshima ${ }^{1,6}$, Ana KR Abadio ${ }^{1}$, Larissa Fernandes ${ }^{7}$, Lorena S Derengowski ${ }^{1}$, Karen S Ferreira ${ }^{8}$, Rangel C Souza ${ }^{2}$, Jeronimo C Ruiz ${ }^{5}$, Nathalia C de Andrade ${ }^{3}$, Hugo C Paes ${ }^{1}$, André M Nicola9, ${ }^{9,}$, Patrícia Albuquerque ${ }^{1,10}$, Alexandra L Gerber², Vicente P Martins' ${ }^{1}$, Luisa DF Peconick', Alan Viggiano Neto' ${ }^{1}$ Claudia B Chaucanez ${ }^{1}$, Patrícia A Silva ${ }^{1}$, Oberdan L Cunha ${ }^{2}$, Fabiana FM de Oliveira ${ }^{1}$, Tayná C dos Santos ${ }^{1}$, Amanda LN Barros ${ }^{1}$, Marco A Soares ${ }^{4}$, Luciana M de Oliveira ${ }^{4,11}$, Marjorie M Marini ${ }^{12}$, Héctor Villalobos-Duno ${ }^{13}$, Marcel ML Cunha ${ }^{3}$, Sybren de Hoog ${ }^{14}$, José F da Silveira ${ }^{12}$, Bernard Henrissat ${ }^{15}$, Gustavo A Niño-Vega ${ }^{13}$, Patrícia S Cisalpino ${ }^{5}$, Héctor M Mora-Montes ${ }^{16}$, Sandro R Almeida ${ }^{17}$, Jason E Stajich ${ }^{18}$, Leila M Lopes-Bezerra ${ }^{3}$, Ana TR Vasconcelos ${ }^{2}$ and Maria SS Felipe ${ }^{1,9^{*}}$

\begin{abstract}
Background: The fungal genus Sporothrix includes at least four human pathogenic species. One of these species, S. brasiliensis, is the causal agent of a major ongoing zoonotic outbreak of sporotrichosis in Brazil. Elsewhere, sapronoses are caused by S. schenckii and S. globosa. The major aims on this comparative genomic study are: 1) to explore the presence of virulence factors in S. schenckii and S. brasiliensis; 2) to compare S. brasiliensis, which is cat-transmitted and infects both humans and cats with S. schenckii, mainly a human pathogen; 3) to compare these two species to other human pathogens (Onygenales) with similar thermo-dimorphic behavior and to other plant-associated Sordariomycetes.

Results: The genomes of S. schenckii and S. brasiliensis were pyrosequenced to 17x and 20x coverage comprising a total of $32.3 \mathrm{Mb}$ and $33.2 \mathrm{Mb}$, respectively. Pair-wise genome alignments revealed that the two species are highly syntenic showing $97.5 \%$ average sequence identity. Phylogenomic analysis reveals that both species diverged about 3.8-4.9 MYA suggesting a recent event of speciation. Transposable elements comprise respectively $0.34 \%$ and $0.62 \%$ of the $S$. schenckii and S. brasiliensis genomes and expansions of Gypsy-like elements was observed reflecting the accumulation of repetitive elements in the S. brasiliensis genome. Mitochondrial genomic comparisons showed the presence of group-I intron encoding homing endonucleases (HE's) exclusively in S. brasiliensis. Analysis of protein family expansions and contractions in the Sporothrix lineage revealed expansion of LysM domain-containing proteins, small GTPases, PKS type1 and leucin-rich proteins. In contrast, a lack of polysaccharide lyase genes that are associated with decay of plants was observed when compared to other Sordariomycetes and dimorphic fungal pathogens, suggesting evolutionary adaptations from a plant pathogenic or saprobic to an animal pathogenic life style.

(Continued on next page)
\end{abstract}

\footnotetext{
* Correspondence: msueliunb@gmail.com

'Departamento de Biologia Celular, Universidade de Brasília, Brasilia, DF, Brazil

${ }^{9}$ Pós-Graduação em Ciências Genômicas e Biotecnologia, Universidade

Católica de Brasília, Brasília, DF, Brazil

Full list of author information is available at the end of the article
} 
(Continued from previous page)

Conclusions: Comparative genomic data suggest a unique ecological shift in the Sporothrix lineage from plantassociation to mammalian parasitism, which contributes to the understanding of how environmental interactions may shape fungal virulence. . Moreover, the striking differences found in comparison with other dimorphic fungi revealed that dimorphism in these close relatives of plant-associated Sordariomycetes is a case of convergent evolution, stressing the importance of this morphogenetic change in fungal pathogenesis.

Keywords: Sporothrix schenckii, Sporothrix brasiliensis, Comparative genomics, Fungal evolution

\section{Background}

The fungal genus Sporothrix includes about 60 species found on all inhabited continents mainly occurring as environmental saprobes, living in association with plants or decaying matter. One lineage within the genus is composed of at least four pathogenic species associated with human and animal sporotrichosis: Sporothrix schenckii sensu stricto, S. brasiliensis, S. globosa, and S. luriei [1-6]. Subcutaneous infections caused by $S$. schenckii are globally endemic [1,2]. Additionally, outbreaks have been described from South Africa, Australia, China and India [7-10]. During the last two decades, an ongoing zoonotic outbreak of sporotrichosis has been observed in Brazil. Initially thought to be caused by Sporothrix schenckii, detailed studies demonstrated that most outbreak isolates were actually $S$. brasiliensis [6].

Sporothricosis is classically associated with rural activities such as agriculture, floriculture or hunting, but more recently felines have emerged as source of human infection. The most common clinical form is a chronic subcutaneous/lymphocutaneous disease acquired after inoculation of fungal material into the skin. Extracutaneous and disseminated forms secondary to cutaneous infection have been described in patients who are immunocompromised as a result of AIDS, chronic alcoholism and diabetes [11]. Rarely, severe cases involving pulmonary infection are noted $[3,4]$.

The pathogens of the genus Sporothrix exhibit a thermodimorphic phenotype: in its saprophytic stage or in in vitro culture at $25^{\circ} \mathrm{C}$ the fungus grows with its filamentous form characterized by hyaline, septate hyphae with sympodial conidiogenous cells that produce two types of spores: hyaline conidia that form clusters and brown, thickwalled spores that are distributed perpendicularly alongside the hyphae. During the parasitic stage, the fungus is found as cigar-shaped yeast cells that can also be obtained in vitro by switching the temperature to $37^{\circ} \mathrm{C}$ [12]. This dimorphism is essential for virulence in the mammalian host $[13,14]$ and is also found in other human pathogenic fungi such as Blastomyces dermatitidis, B. gilchristii, Histoplasma capsulatum, Paracoccidioides brasiliensis, $P$. lutzii, Coccidioides immitis and C. posadasi. However, all of these other dimorphic fungi are members of the order Onygenales, phylogenetically distant from Sporothrix in the Ophiostomatales [15]. The long genetic distance between these two orders suggests that thermo-dimorphism is a convergent phenotype shared by only a few members of these two orders. Genes such as histidine kinase (drk1) regulates the transition of mycelium to yeast and consequently the maintenance of virulence in $B$. dermatitidis and $H$. capsulatum [16]. This gene, also identified in S. schenckii, shows $65 \%$ of identity with its ortholog in B.dermatitidis and seems to be highly expressed during the yeast stage [17].

Besides dimorphism and thermo-tolerance, current knowledge about virulence factors of Sporothrix remains scant. The cell surface of pathogenic fungi plays a key role in the host-fungus interplay, mediating various processes associated with pathogenesis. The fungal cell wall is mainly composed of glycoconjugates: structural polysaccharides such as chitin and $\beta$-glucans, and cell wall glycoproteins [18]. Few proteins and glycoconjugates have been identified so far in the $S$. schenckii cell wall and their relevance for the host-fungus interaction and stimulation of the host immune system was reinforced by recent studies $[19,20]$. However, the identity of the enzymes involved in biosynthetic pathways of cell wall components is still lacking. Another cell wall virulence factor, melanin, was found in S. schenckii conidia and yeast cells being produced in vitro or in vivo during infection [21]. Melanin pigments protect the fungus from the mammalian host's innate immune responses providing resistance to oxidizing agents and fungal cell death during phagocytosis [22,23].

Members of the pathogenic lineage in Sporothrix seem to behave in the host remarkably different from Ophiostoma species, suggesting a fundamental habitat shift from a plant- to a mammal-associated life style [24]. Remarkably, most fungi from the order Ophiostomatales live in association with bark beetles in woody plants, displaying adaptation strategies for insect transmission that are very different from those of S. schenckii and their relatives [2,25]. The main biological questions of this work revolve around the dimorphic and pathogenic status of the two Sporothrix species, which are phenotypically similar to human/animal pathogenic Onygenales but philogenetically closely related to plant-associated Sordariomycetes. To address these questions, we performed 
a comparative genomic analysis of the pathogens with 14 other fungi, either dimorphic pathogens or plant-associated Sordariomycetes. Of these, we chose the closest relative to the Sporothrix lineage, Grosmannia clavigera, for more detailed comparison. G. clavigera is a tree-pathogenic and insect-associated fungus from a related genus from the Ophiostomatales order [26]. It is a haploid filamentous Ascomycete and a symbiont of the bark beetle Dendroctonus ponderosae, which affects commercial conifer forests, parks, protected areas and urban forests across North America [27]. These genomic analyses allowed us to identify the core genes for general and secondary metabolism as well genes related to autophagy, adhesion, cell wall assembly and melanin biosynthetic processes. We have also shown that genomic adaptation in the Sporothrix lineage has led to expansion of some protein domains and lack of genes associated with plant biomass decay when compared to other Sordariomycetes, which can be interpreted as an adaptation from plant to an animal associated life style.

\section{Results and discussion}

Genomes features, assemblies and synteny

The S. schenckii and S. brasiliensis genomes were each pyrosequenced to $\sim 20 \mathrm{x}$ coverage. The $S$. schenckii genome (strain 1099-18) yielded 16 scaffolds with N50 of 4.3 Mb, containing 237 contigs comprising a total size of 32.4 Mb. The $S$. brasiliensis genome (strain 5110) yielded 13 scaffolds with $\mathrm{N} 50$ of $3.8 \mathrm{Mb}$, containing 601 contigs, had a total genome size of $33.2 \mathrm{Mb}$, and shared similar genomic characteristics with G. clavigera [26] (Table 1). Telomeric repeats (TTAGGG/CCCTAA) $n$ were found at 5 ' or 3' terminal ends of 5 out of 13 scaffolds in the S. schenckii and 7 out of 13 scaffolds in the S. brasiliensis genome. Terminal repeats were found in both ends of 1 and 3 scaffolds of $S$. schenckii and S. brasiliensis respectively,

Table 1 Sporothrix genome characteristics

\begin{tabular}{llll}
\hline Characteristic & S. schenckii & S. brasiliensis & G. clavigera* \\
\hline Genome size & $32.4 \mathrm{Mb}$ & $33.2 \mathrm{Mb}$ & $29.8 \mathrm{Mb}$ \\
Coverage & $17 \mathrm{X}$ & $20 \mathrm{X}$ & $64 \mathrm{X}$ \\
Supercontig number & 16 & 13 & 18 \\
N50 supercontig & $4.3 \mathrm{Mb}$ & $3.8 \mathrm{Mb}$ & $1.2 \mathrm{Mb}$ \\
G+C content & $62 \%$ & $62 \%$ & $53.4 \%$ \\
Protein coding genes & 10,293 & 9,091 & 8,314 \\
Median Transcript length & $1,522 \mathrm{bp}$ & $1,602 \mathrm{bp}$ & $1,641 \mathrm{bp}$ \\
Introns per gene & 1.0 & 1.1 & 1.9 \\
Median Intron length & $91.2 \mathrm{bp}$ & $123.4 \mathrm{bp}$ & $70 \mathrm{bp}$ \\
Median Intergenic distance & $1,530 \mathrm{bp}$ & $1,913 \mathrm{bp}$ & $1,466 \mathrm{bp}$ \\
tRNA & 139 & 140 & 268 \\
\hline
\end{tabular}

*Genomic information collected according previously published G. clavirera genome [26]. revealing the presence of complete linear chromosomes. Pair-wise genome alignments showed that both Sporothrix species are highly syntenic sharing $97.5 \%$ average sequence identity (Figure 1A). According to the genomic alignments long inverted segments were found in the two Sporothrix genomes (Figure 1A-C). S. schenckii and S. brasiliensis were predicted to have 10,293 and 9,091 protein coding genes respectively, similar to other Eurotiomycetes and Sordariomycetes, and slightly higher than G. clavigera (Table 1). The $\mathrm{G}+\mathrm{C}$ content in S. schenckii and $S$. brasiliensis genomes is one of the highest in Ascomycota. S. schenckii and S. brasiliensis genomes display $62 \%$ of $\mathrm{G}+\mathrm{C}$ contents in both species, which is considerably higher than G. clavigera (53.4\%) [26] and 50-52\% in most other fungi in Pezizomycotina [28]. We detected similar distributions of transcript lengths, but we found less introns per gene in Sporothrix genomes than in those of G. clavigera. The tRNA contents revealed a great discrepancy among the analyzed fungi; G. clavigera harbors at least 2-fold more tRNAs than Sporothrix genomes (Table 1). We analyzed the homology relationships among fungi from the Ophiostomataceae family, comparing the gene content of S. schenckii, S. brasiliensis and G. clavigera by Bidirectional-best Blast Hits (BBH). A total of 4,788 genes were found in all three genomes and 2,001 were found to be Sporothrix-restricted genes, indicating a high content of specific genes in the Sporothrix lineage. A total of 1,549 and 508 genes were considered orphan sequences in S. schenckii and S. brasiliensis, respectively (Figure $1 \mathrm{~B}$ ). We have performed the comparative analysis of core genes involved in general and secondary metabolism, as well genes involved in transport and catabolism showing a high degree of conservation when compared to those present in other Ascomycetes (Additional file 1: Text 1). Genomes from S. schenckii and S. brasiliensis were deposited in the Genbank under respectively accession numbers: AXCR00000000 and AWTV00000000.

\section{Phylogenomic analysis}

A total of 395 orthologous protein clusters were identified by $\mathrm{BBH}$ after searching 25 fungal genomes, including Ascomycetes, Basidiomycetes and Chytridiomycetes (Additional file 2: Table S1). A Maximum Likelihood phylogenomic tree was generated using a 153,436 amino acids position alignment and calibrated with the origin of Ascomycota clade around 500-650 MYA. The phylogenomic tree, as expected, placed S. schenckii and S. brasiliensis in a monophyletic clade closest to G. clavigera being apart from other Sordariomycetes (Figure 2). According to the phylogenomic tree, S. schenckii and S. brasiliensis diverged about 3.8-4.9 MYA suggesting a recent event of speciation in the genus Sporothrix. Additionally, evolutionary origin of the ophiostomatoid 


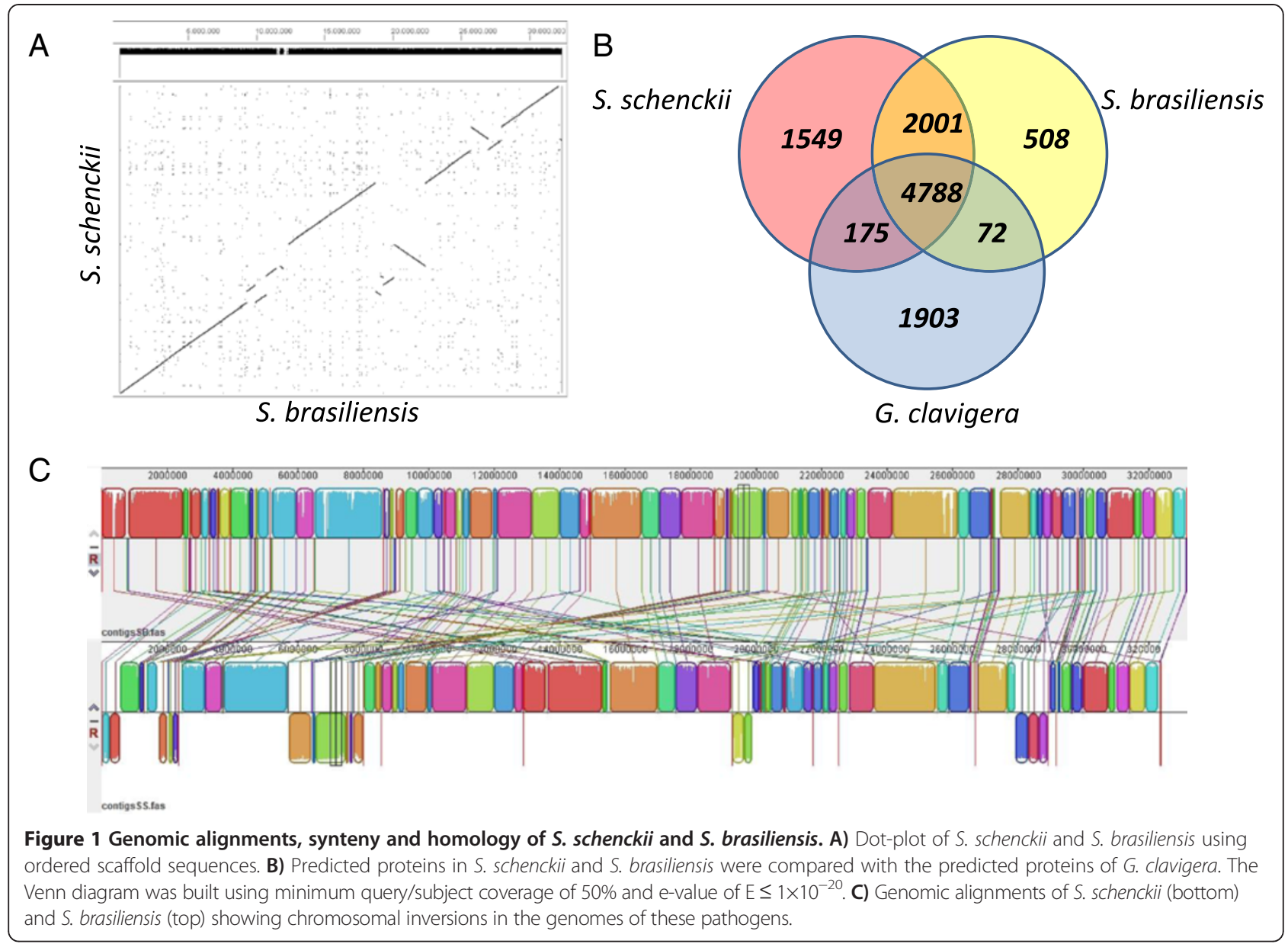

fungi was dated to 69.1-89.9 MYA, being highly divergent from the plant pathogen G. clavigera (Figure 2). The divergence time varied across sister species of fungal pathogens along the Ascomycota phylum, such as $C$. immitis vs. C. posadasii diverged about 5.1 Mya [29] and P. brasiliensis vs. P. lutzii about 11 to 32 Mya [30].

\section{Mitochondrial genomic comparisons}

The mitochondrial genome assembly of S. schenckii strain $1099-18$ is $26.5 \mathrm{~Kb}$ in size and shares $99-100 \%$ average sequence identity and $97-100 \%$ coverage in comparison to that of previously published S. schenckii strains ATCC 10268 (AB568599) and KMU2052 (AB568600) (data not shown). The mitochondrial genome assembly of $S$. brasiliensis strain 5110 spans $36 \mathrm{~Kb}$ but covers only $71-75 \%$ of the three $S$. schenckii mentioned genomes before. Despite the high similarity between the two analyzed mitochondrial genomes (99\% of identity), S. brasiliensis harbors parasitic group-I intron encoding homing endonucleases (HE's) which is responsible for the higher mitochondrial genome size in this species. Those elements were detected in the cytochrome $\mathrm{C}$ oxidase 1 , ATP synthase subunit 6 and between $\mathrm{NADH}$ dehydrogenase subunits 2 and 3
ORF's (Figure 3). These HE's found in the S. brasiliensis mitochondrial genome were classified into two families according Interpro domain screening: LAGLIDADG and GIY-YIG. Mitochondrial LAGLIDADG HE's from $S$. brasiliensis (SPBR09268, SPBR09281 and SPBR09282) shared $75 \%, 84 \%$ and $78 \%$ of identity to Madurella mycetomatis (YP_006576197), Fusarium graminearum (YP_001249331) and F. solani (YP_005088115), respectively. The S. brasiliensis mitochondrial GIY-YIG HE (SPBR09426 and SPBR09429) is highly conserved among other Sordarimycetes, sharing $72 \%$ and $77 \%$ of identity to Podospora anserina (NP_074919) and Ceratocystis cacofunesta (YP_007507073), respectively . C. cacofunesta contains 37 intronic ORFs, thus being responsible for one of the largest mitochondrial genomes among Sordariomycetes [31]. Fungal mitochondrial genomes present a constant genetic mobility, probably due to the activity of group-I intron encoding homing endonucleases. Mitochondrial introns and their ORFs have been associated with mitochondrial parasitism and genomic size changes thus causing genomic instability, which was reported before in S. cereviseae, $P$. anserina, Neurospora crassa, Ophiostoma and Aspergillus [32-36]. According to the phylogenetic tree, 


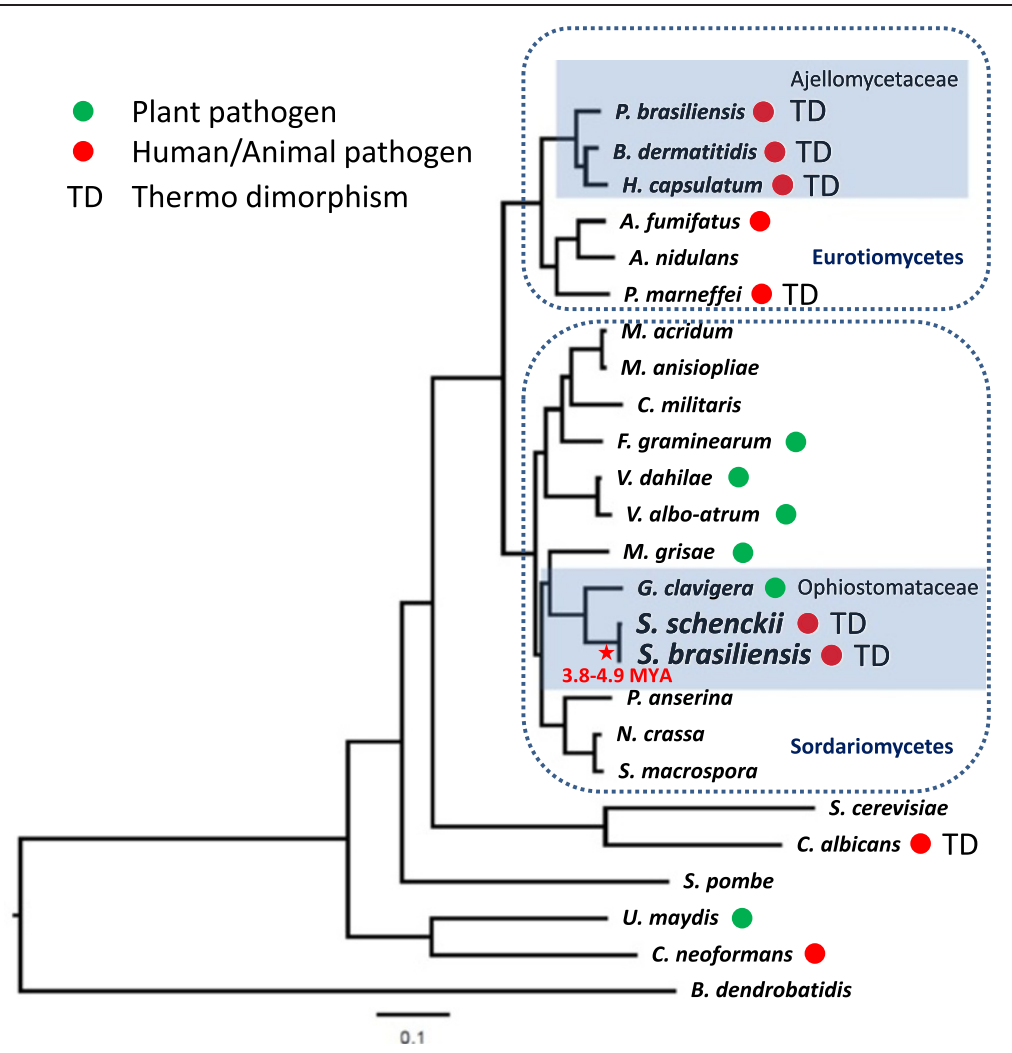

Figure 2 Phylogenomic relationships of Sporothrix species and other thermodimorphic fungal pathogens. The phylogenetic tree was constructed from an alignment of 153,436 amino acids of 395 orthologous protein clusters. The tree was inferred by Maximum Likelihood method implemented in RAxML and Dayhoff amino acid substitution was used as the best protein substitution model. The tree was calibrated with the origin of the Ascomycota clade around 500-650 MYA.

no common ancestor was found in Sordariomycetes class, suggesting an independent or convergent evolution of group-I intron encoding LAGLIDADG and GIYYIG elements in Ascomycota (Figure 3).

\section{Transposable elements expansions in S. brasiliensis genome}

Transposable elements (TEs) comprise $0.34 \%$ and $0.62 \%$ of the S. schenckii and S. brasiliensis genomes, respectively (Table 2). Fungal genomes contain substantially different amounts of repetitive DNA sequences. The assembled genome of Magnaporthe oryzae contains $10.8 \%$ of repetitive DNA sequences, in $M$. grisea it is $4.2 \%$, in $N$. crassa is $10 \%$ and in S. cerevisiae almost 6\% [37-40]. Differences in the TE contents are observed even between closely related species, e.g. in the genus Paracoccidioides. In $P$. brasiliensis TEs correspond to $8-9 \%$ of the genome and twice this amount in P. lutzii (16\%) [41]. Although less common, lower TE contents have been described in other fungi, for example $0.48 \%$ of Trichoderma and $0.1 \%$ of Fusarium graminearum genomes assemblies [39,42].
Despite their lower content in Sporothrix genome, all classes of TEs have been detected with large variation in number and diversity between $S$. schenckii and S. brasiliensis. Two major types of retrotransposons, LINEs and LTRs, were found in S. schenckii and S. brasiliensis, but no SINE elements were found (Table 2). In S. brasiliensis, a five-fold expansion of Gypsy-like elements was observed compared to S. schenckii and both genomes contain more Gypsy-like elements than Copia-like elements. We have observed a 4 and 19 foldchange between Gypsy-like and Copia-like elements for S. schenckii and S. brasiliensis respectively, as usual for fungal genomes [38]. The overall 2-fold expansion of repetitive sequence content between Sporothrix species may reflect an expansion of retrotransposons in the S. brasiliensis genome or either a contraction in that of S. schenckii (Figure 4). According to population genomics studies and mating type distribution, the S. brasiliensis population appears to be clonal and no recombination events were detected [43]. We observed a predominance of a single mating clone in epidemics of sporotrichosis and no or limiting sex could favor the accumulation of 


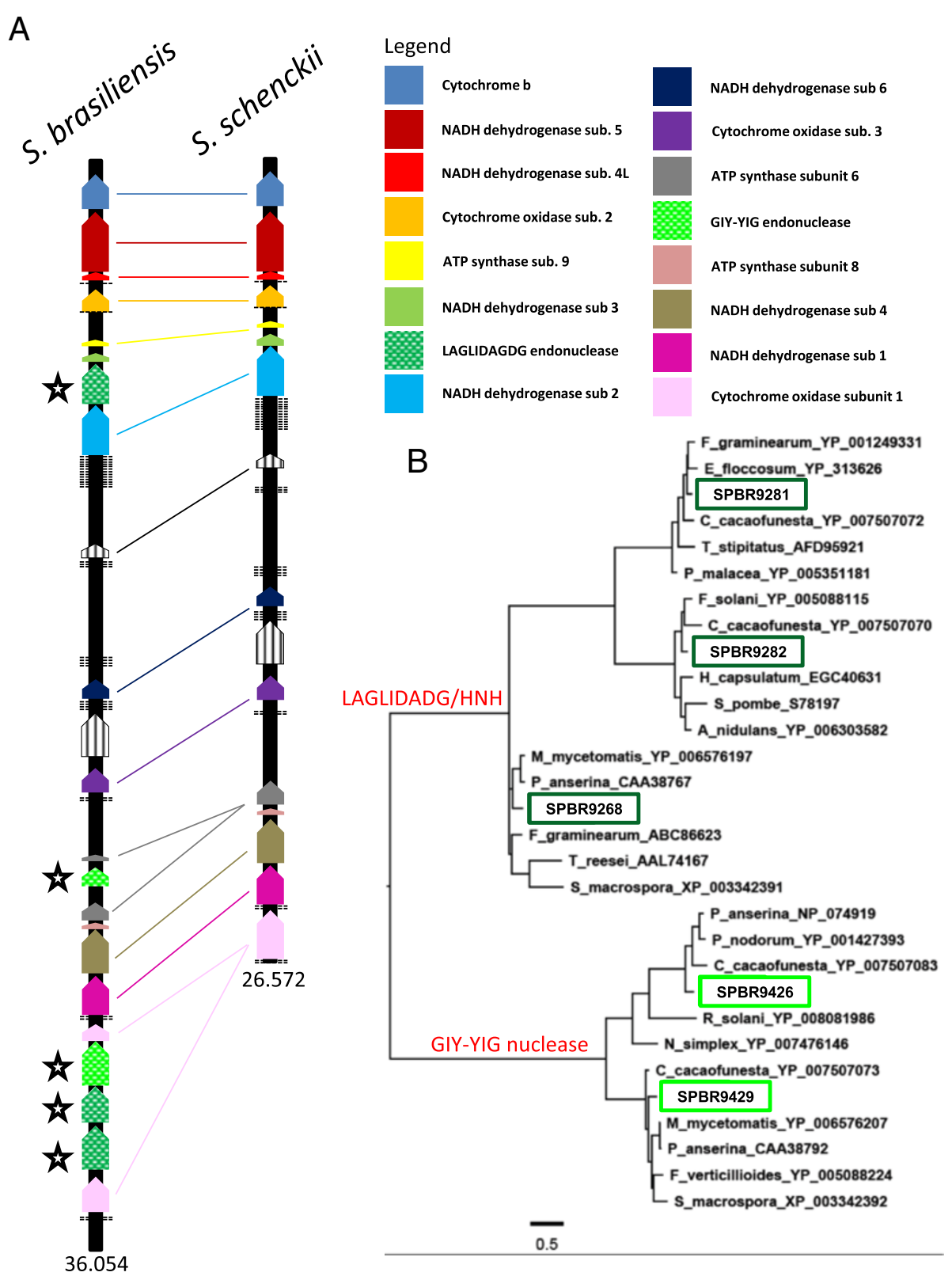

Figure 3 Comparative analysis of mitochondrial genomes of S. schenckii and S. brasiliensis. (A) Gene content and order in mitochondrial genomes of S. schenckii vs. S. brasiliensis showing high synteny despite the considerable difference in size. Insertions of LAGLIDADG and GIY-YIG intron I type homing endonucleases in S. brasiliensis are present inside cytochrome C oxidase 1, ATP synthase subunit 6 and NADH dehydrogenase subunits 2 and 3 genes. (B) Phylogenetic analysis was performed using the five LAGLIDADG or GIY-YIG elements found in S. brasiliensis showing no pattern of ancestry with other close related species.

repetitive elements in microorganisms genomes [44,45]. Assexual propagation could lead extinction due inability to control proliferation of vertically transmitted TEs, as accumulation occurs due to the inefficiency of purifying selection in clonal species [46].

Equivalent numbers of DNA transposons were found in S. schenckii and S. brasiliensis genomes. hAT-like elements were the most prevalent in both species (Table 2). Transposons from Tc1/mariner and Mutator superfamilies were also found in both genomes. Four copies of Helitrons were identified in S. brasiliensis while a PiggyBac-like element was detected only in S. schenckii. Almost all TEs identified in Sporothrix genomes corresponded to defective and truncated copies, with exception of one LINE-like element found in S. schenckii, suggesting that Sporothrix species are able to control their proliferation. This finding suggests that TEs are present in Sporothrix but with low transposition activity. We discuss why this could be below. 
Table 2 Transposable element composition in Sporothrix genomes

\begin{tabular}{lll}
\hline Type & S. schenckii & S. brasiliensis \\
\hline LTR - Copia-like & 3 & 3 \\
LTR - Gypsy-like & 12 & 57 \\
LTR - BelPao-like & 1 & 0 \\
LINE & $14(1)^{\text {a }}$ & 7 \\
Tc1/mariner-like & 9 & 6 \\
hAT-like & 12 & 9 \\
Mutator-like & 1 & 4 \\
PiggyBac -like & 1 & 0 \\
Helitron & 0 & 4 \\
Total elements & 53 & 90 \\
Percent of assembly & $0.34 \%$ & $0.62 \%$ \\
\hline
\end{tabular}

${ }^{a}$ The number of potentially functional elements is shown in parentheses.

\section{Protein family expansion and contraction in the Sporothrix lineages}

Gene duplications are an important source of evolutionary innovation and new gene copies can evolve new adaptive functions shaping an organism's gene content. The differences among gene families have been related to emerging processes due to differential degrees of genetic drift, and thus the effectiveness of selection, acting on genomes [47]. The pathogenic phenotypes of S. schenckii and S. brasiliensis could result of expansion in specific gene families that confer advantages in the interaction with human/animal hosts. On the other hand, gene families that ate necessary for the plant-associated lifestyles of other Sordariomycetes could be contracted. To test these hypotheses, we have compared the genomes from closely related Sordariomycetes and dimorphic fungal pathogens. Changes in S. schenckii and S. brasiliensis gene families were inferred based on domain expansions or contractions assigned by Interpro, Pfam and SMART databases and statistically tested by hypergeometric comparisons $(\mathrm{P}<0.05$ - Figure 5, Additional file 3: Figure S2, Additional file 4: Figure S3 and Additional file 5: Figure S4) and the reported p-values were used for multiple testing using q-value.

We have not observed the enrichment of peptidases genes in Sporothrix lineage, specifically the MEROPS families M35 or M36, which are expanded in dimorphic fungal pathogens as adaptation to mammalian hosts $[29,41]$. On the other hand, we observe a lack of polysaccharide lyase genes which are associated with decay of plants (CAZy PL family) when compared to other Sordariomycetes (Figure 6A, Additional file 2: Table S5). The subfamilies PL1, PL3 and PL4 are broadly distributed among Sordariomycetes, but were not observed in the Sporothrix species. Interestingly loss of plant degrading enzymes were also observed in other dimorphic fungal pathogens such as $H$. capsulatum and C. immitis (Figure 6A, Additional file 2: Table S5), which has also been previously interpreted as adaptation from plants to animals $[29,41]$. As an alternative for the absence of PL

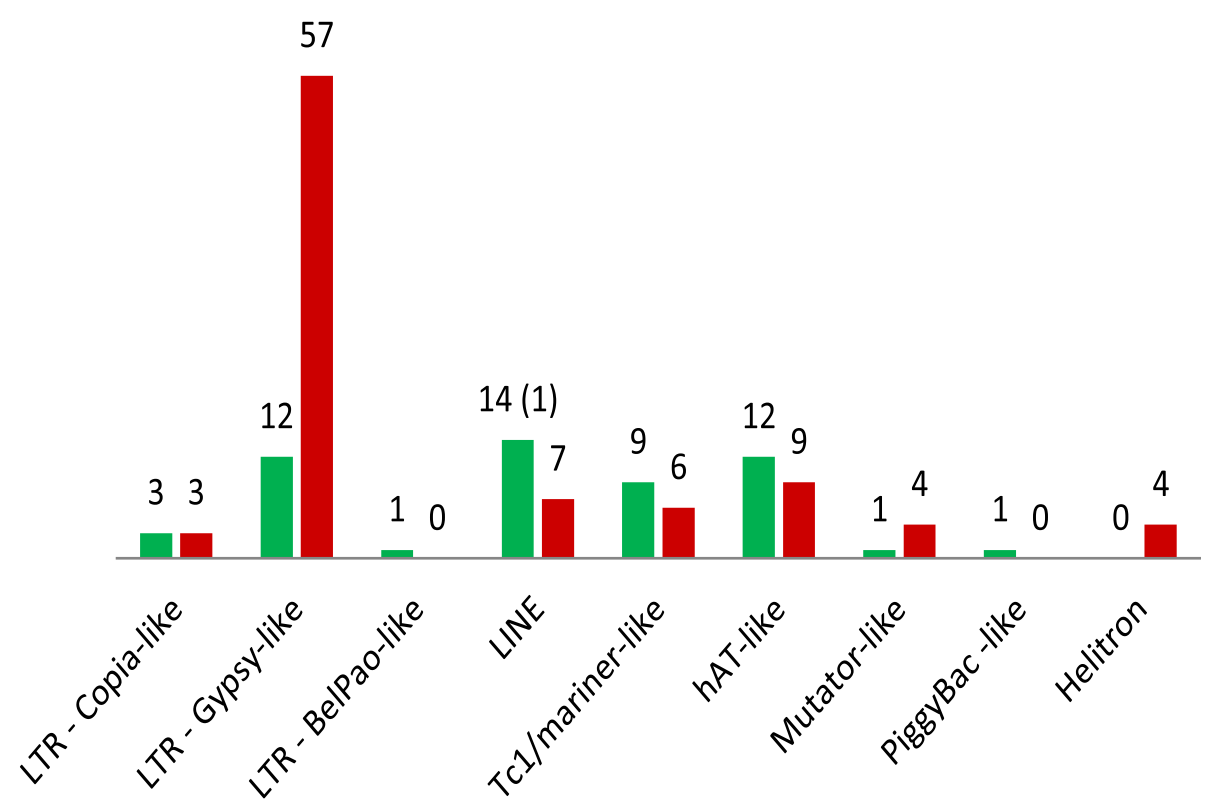

Figure 4 Transposable element content in Sporothrix schenckii and S. brasiliensis genomes. The number of potentially functional elements is shown in parentheses. 


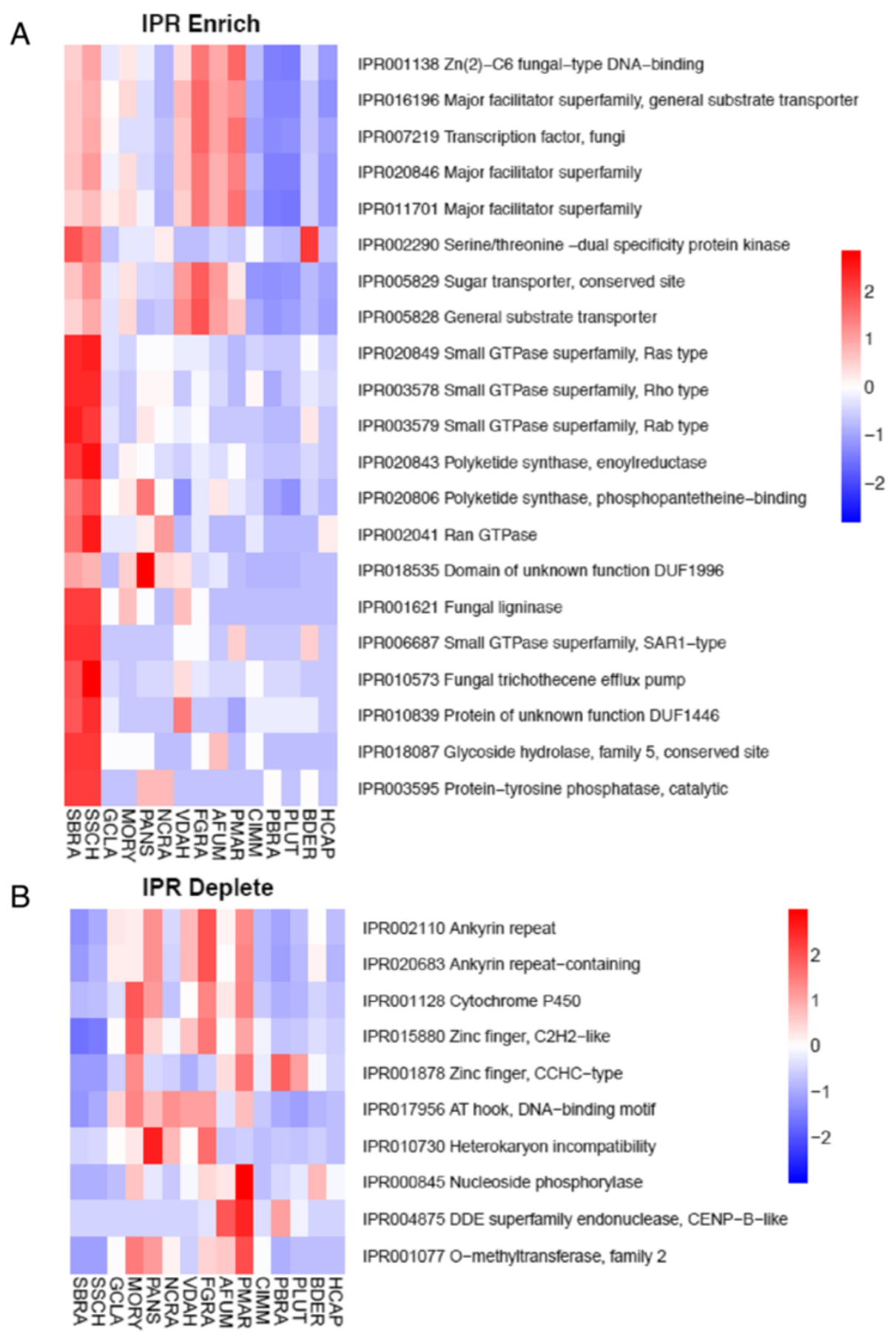

Figure 5 Interpro domains most enriched (A) or depleted (B) in Sporothrix lineages compared to other thermo dimorphic fungi and close related Sordariomycetes. SBRA - S. brasiliensis, SSCH - S. schenckii, GCLA - G. clavigera, MORY - M. oryzae, PANS - P. anserina, NCRA - N. crassa, VDAH - V. dahliae, FGRA - F. graminearum, AFUM - A. fumigatus, PMAR - P. marneffei, CIM - C. immitis, PBRA - P. brasiliensis, PLUT - P. lutzii, BDER - B. dermatitidis, HCAP - H. capsulatum. The reported $p$-values were used for multiple testing using q-value.

proteins, it may be hypothesized that Sporothrix may digest pectin by using polygalactouronase (CAZy GH28) as a replacement strategy. Additionally, we didn't detect any GH72 genes in Sporothrix genomes although those genes were found in all remaining analyzed fungi (Additional file 2: Table S5).

LysM domain-containing proteins display carbohydrate binding modules, usually $42-48$ amino acids residues in 


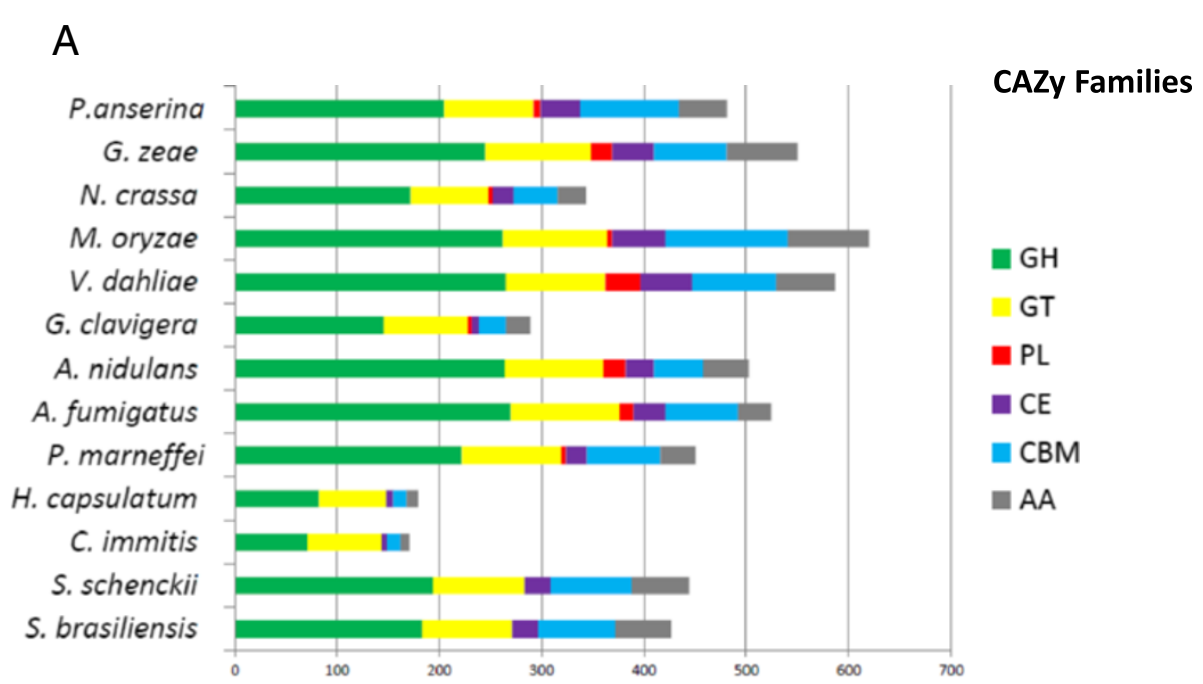

B

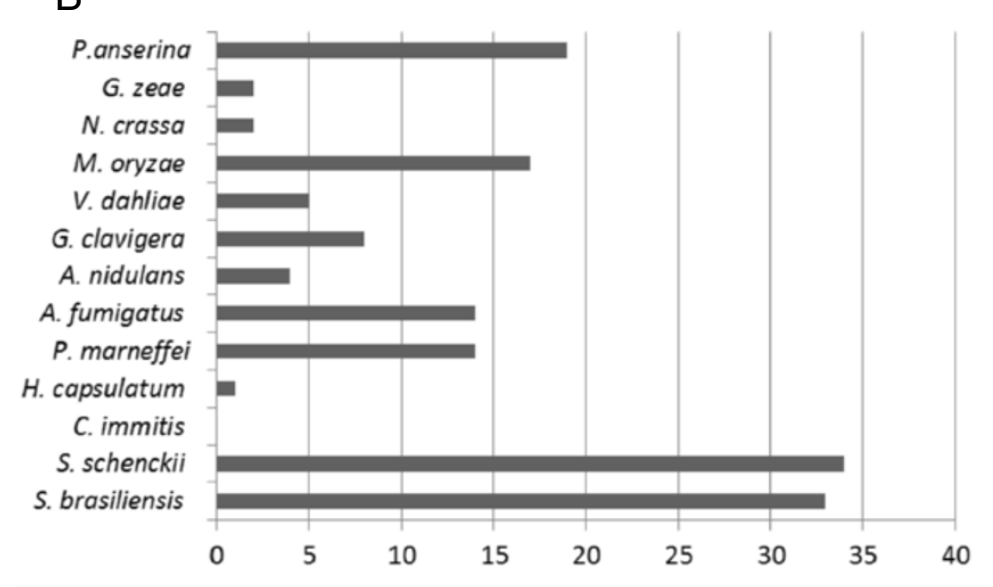

CBM 50

Figure 6 Gene expansion/contraction of carbohydrate-active enzymes (CAZy) in the genus Sporothrix. (A) Overall comparison of Glycoside Hydrolases (GHs), Glycosyl Transferases (GTs), Polysaccharide Lyases (PLs), Carbohydrate Esterases (CEs), Auxiliary Activities (AAs) and Carbohydrate-Binding Modules (CBMs) against other thermo dimorphic fungi and closely related Sordariomycetes. (B) CBM 50 gene family is highly expanded in the Sporothrix lineage.

length, found in prokaryotes and eukaryotes. These proteins are classified in the CAZy database as CBM family 50 and harbor $\mathrm{N}$-acetylglucosamine (GlcNAc) binding characteristics. According to PFAM and CAZy counts, a marked expansion of the LysM domain PF01476 (CAZy CBM family 50) was detected in the Sporothrix lineage. The phylogenetic tree clearly showed highly expanded branches in the Sporothrix lineage when compared to other Sordariomycetes and thermo dimorphic fungal pathogens (Figure 7). Moreover, the comparative analysis of CAZy CBM family 50 also revealed a high expansion of this domain (Figure 6B, Additional file 2: Table S5). Recent events of duplications of LysM homologs subsequent to a speciation event were detected in the Sporothrix lineage using reconciled tree approach (Additional file 6: Figure S1). The first duplication (Figure 7, clade I) is related to genes containing single or multiple repetitions of LysM domains, chitin-binding module type 1 (CBM18) plus glycoside hydrolase (GH18). The second event of duplication was observed in genes harboring multiple copies of LysM, providing evidence of recent intergene duplication of this domain within paralogues (Figure 7, clade II). The structure of Sporothrix LysM domain-containing genes are presented separately in Additional file 3: Figure S2.

Chitin is a linear polymer of $\beta$-(1,4)-linked GlcNAc, and is one of the major components of fungal cell wall. The absence of chitin in mammalian cells makes this polymer a potential targets for the innate immune system [48]. Chitin can be recognized by mammalian cells, and is bound and degraded by chitin-binding proteins GH18, playing an important role in inflammation and 


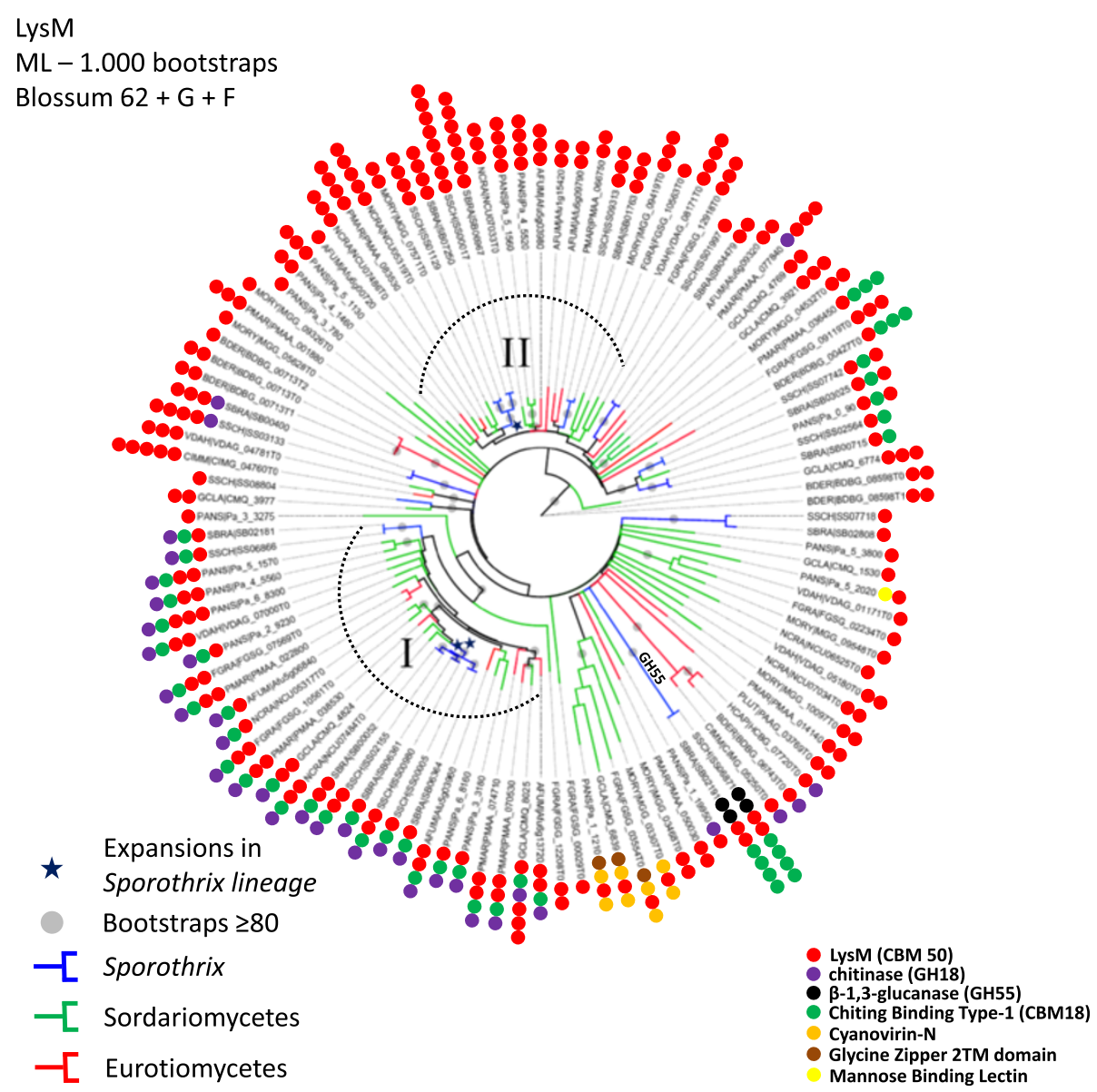

Figure 7 Unrooted maximum likelihood tree revealing LysM expansions in the Sporothrix lineage. Two major expansions were detected: The first duplication is related to genes containing single or multiple repetitions of LysM domains (CBM50), chitin binding module type 1 (CBM18) plus glycoside hydrolase (GH18) - clade I. The second event of duplication was observed in genes presenting multiple copies of LysM (CBM50), and is evidence of recent intergene duplication of this domain within paralogous - clade II.

innate and adaptive immunity based on their modulation on various disease states [49]. Chitin can mask immune recognition by blocking dectin-1-mediated interaction with fungal cell walls [50]. Also, chitin modulates epithelial immunity of the skin expressing high levels of cytokine and chemokine and increases TLR4 expression on keratinocytes [51]. Possibly these proteins are present to bind the own Sporothrix chitin exposed upon cell damage, and in this way it may protect itself against recognition of this polymer by keratinocytes. LysM effector (Ecp6) from Cladosporium fulvum was characterized as a virulence factor of this phytopathogenic fungus on tomato plants. Carbohydrate binding assays have shown that Ecp6 specifically binds to chitin, the major constituent of the fungal cell wall, acting as a PAMP upon recognition by the plant during fungal invasion. The presence of chitin-binding effector Ecp6 in the apoplast masks the perception of chitin by plant receptors preventing the activation of defense responses [52]. In addition significant expansion of the LysM domain was detected in dermatophytes, compared to the thermodimorphic fungi [53]. Dermatophytosis and sporotrichosis are characterized as cutaneous mycoses and the infection is acquired after contact and/or trauma of skin. LysM domain containing proteins have not been characterized as virulence factors in human or animal fungal pathogens so far, and the role of those proteins requires further investigation and could be a novel mechanism for fungal evasion in mammalian host tissue.

Small GTPases are an independent superfamily of GTP-binding proteins, sharing a common enzymatic activity and producing GDP by the hydrolysis of GTP, and play pivotal roles in cell division and signaling, vesicle fusion and protein synthesis [54]. These proteins are also involved in filamentation, mating, growth at $37^{\circ} \mathrm{C}$ and virulence in C. neoformans [55,56]. Significant expansions in Ras, Rho and Rab Small GTPase superfamilies (IPR020849, IPR003578 and IPR003579) were observed in the Sporothrix lineage when compared to other Ascomycetes (Figure 5, Additional file 2: 
Table S4). Judging from the phylogenetic trees of small GTPases, the majority of branches harboring Sporothrix homologues suggests a higher diversity among the Ascomycetes we analyzed (Additional file 4: Figures S3, Additional file 5: Figure S4, Additional file 7: Figure S5). Reconciliation of small GTPases gene trees and species tree do not indicate Sporothrix-specific duplications, that instead independent gene losses in other species explain the increased copy number in Sporothrix (Additional file 8: Figure S6, Additional file 9: Figure S7, Additional file 10: Figure S8). An alternative hypothesis is that the Sporothrix Ras, Rho and Rab genes have duplicated recently and rapidly diverged creating the observed long branch lengths. In addition we detected highly supported clades containing Sporothrix and other pathogenic dimorphic fungi, suggesting convergent evolution of small GTPases, reinforcing the high plasticity of signal transduction in the Sporothrix lineage (Additional file 4: Figure S3, Additional file 5: Figure S4, Additional file 7: Figure S5). To date, such a high diversity of Small GTPase proteins as found in the Sporothrix lineage has not been reported from any other class of fungi.

Another group that was expanded by INTERPRO and SMART domain counts in the Sporothrix lineage is the polyketide synthase (PKS), enoylreductase (IPR020843) family (Figure 5, Additional file 2: Tables S3, S4). Polyketides comprises diverse fungal secondary metabolites such as antibiotics, pigments, and mycotoxins that are formed from simple carbon precursor acids catalyzed by polyketide synthases (PKSs) [57]. Filamentous fungi are producers of polyketide metabolites, several of which of pharmacological or agricultural interest [58,59]. Fungal PKSs are in general a linear succession of ketosynthetase (KS), acyltransferase (AT), dehydratase (DH), enoyl reductase (ER), ketoreductase (KR), acyl carrier protein (ACP), and thioesterase (TE) domains [60]. ER domains reduce enoyl groups to alkyl groups (saturated) during production of secondary metabolites. Among fungal genomes, few potential PKS orthologous genes are shared, even between closely related taxa [61]. We identified various paralogous duplications in the phylogenetic analysis of PKS-containing protein, and the Sporothrix lineage appears to have of PKS-encoding genes that is at least 3-fold larger than that of the other species analyzed (Additional file 2: Table S4, Figure 8). This was confirmed using the reconciled approach of PKS gene tree with the species tree analyzed (Additional file 10: Figure S8). Convergent branches linking Sporothrix and other pathogenic dimorphic fungi were also observed. We identified discontinuous distributions of PKS homologs among the analyzed fungal species, with low bootstrap values, that can be explained by gene duplication, divergence, and gene loss [61]. We also identified expanded clades harboring Sporothrix and dimorphic fungi with high branch support values, suggesting a great diversity of this protein family.

Another large expansion found in the Sporothrix lineage is a fungal trichothecene efflux pump (Pfam PF06609), an evidence of detoxification via mycotoxin pump [62]. Apart from that, fungal genomes generally harbor a lower content of Leucine-rich repeat (LRR) proteins than other ophistokonts [63]. Gene expansions of several LRR superfamilies were identified in the Sporothrix lineage (Additional file 2: Tables S3, S4). LRR proteins expansions are commonly found in eukaryotic parasites such as Trypanosoma and Giardia [64,65]. These domains consist of 2-45 motifs of 20-30 amino acids in length providing a structural framework for protein-protein interactions. LRR proteins are involved in a variety of biological processes and are source of genetic variation for the ongoing process of antigenic variability in pathogens $[66,67]$. In addition expansion of LRR proteins was described for Candida species as a virulence factor [68]. The role of these proteins should be further investigated in the genus Sporothrix.

\section{Cellular processes and dimorphism}

The basic mechanisms of DNA repair in Sporothrix do not deviate from the eukaryotic consensus, as expected, but neither S. brasiliensis nor S. schenckii seem to have a homolog to the Neurospora crassa RIP-defective (RID) methyl-transferase [69]. This suggests that RIP-like mutation patterns found in transposable elements in this fungus are not generated by the classical, RID-dependent mechanism. This is not a surprise, given that at least one previous report [70] pointed to the possibility of alternative pathways for repetitive DNA quelling via RIP. This is in contrast to other Sordariomycetes and even more distantly related members of the Ascomycota, such as $P$. brasiliensis and $H$. capsulatum, for which the tBLASTn tool yielded hits with high homology. Since the number of degenerate TEs and overall evidence of transposon activity in Sporothrix spp. genomes is low, it would be interesting to identify which pathway is responsible for TE suppression in this genus instead of RIP. We also note the absence of a mus-18 homologue for the alternative, UV damage-related nucleotide excision repair pathway [71], found in Neurospora crassa.

Among transcription factors, the recent discovery of the Ryp1 protein in $H$. capsulatum [72] is of interest for the study of adaptive processes in fungi. Ryp1 and its homologues in C. albicans and S. cerevisiae [73] are all implicated in morphogenetic changes of their respective species in response to environmental stimuli. We have also found an ortholog of Ryp1 in Sporothrix. Given that Ryp1 and the hybrid histidine-kinase Drk1 are two determinants of mold-to-yeast transition in dimorphic fungi, and that Sporothrix also has homologues for the 


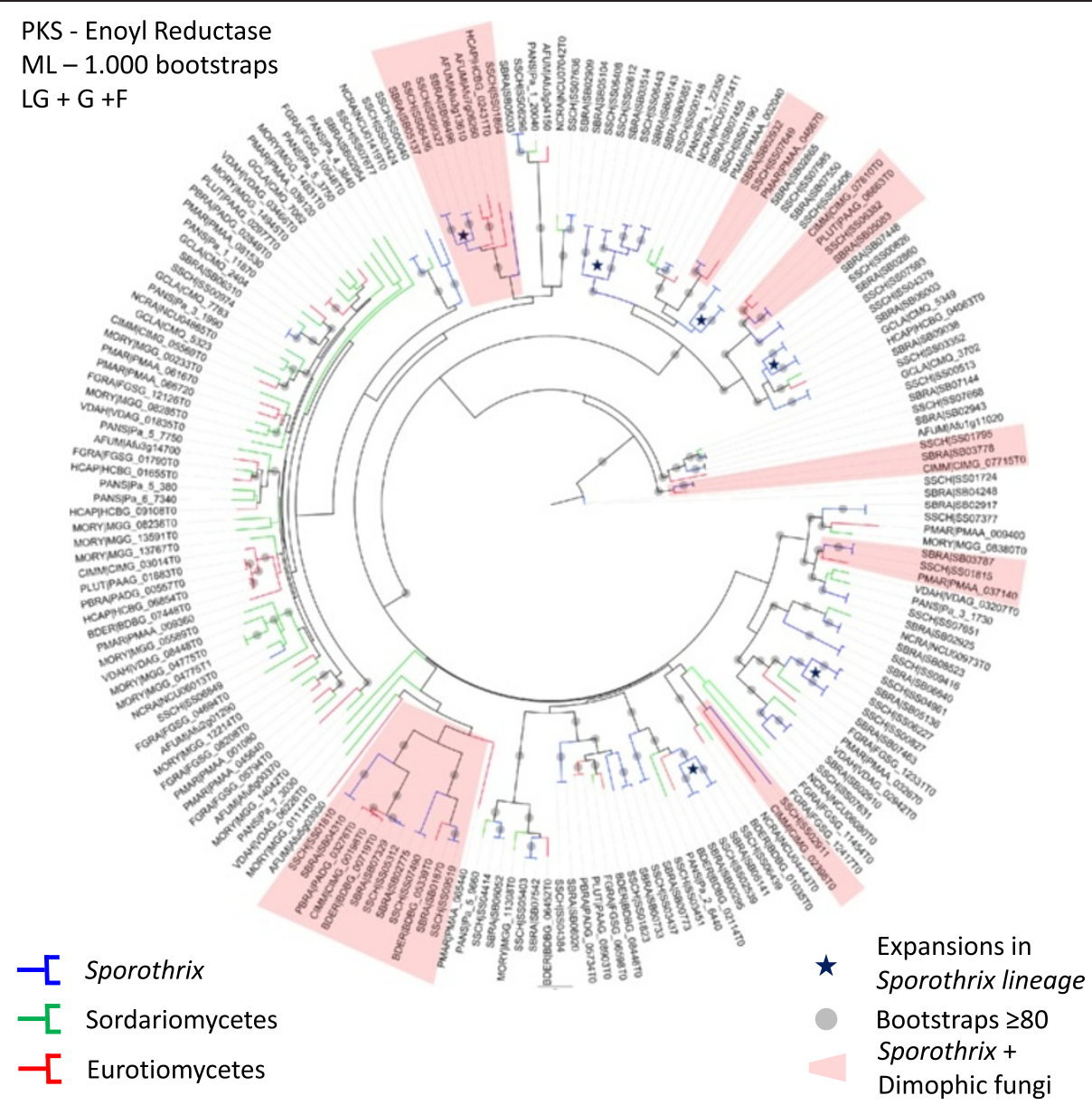

Figure 8 Unrooted maximum likelihood tree of Polyketide synthase (PKS) enoylreductase (IPR020843) family showing expansions in the Sporothrix lineage. Paralogous duplications are displayed in the related branches suggesting vast genomic apparatus of PKS containing genes in the Sporothrix lineage. Clades harboring Sporothrix and dimorphic fungi are displayed in red.

latter [16], it seems reasonable to speculate that both also have been coopted by this genus to coordinate dimorphic transition.

\section{Cell wall assembly}

The cell wall of fungi is a dynamic organelle, which is constantly adjusted depending on environmental insults. Fungal cell wall components are considered relevant for virulence, have antigenic properties and participate in the modulation of the host immune response by being recognized by innate immunity receptors [14]. Current models propose an arrangement of several stratified layers composed of structural polysaccharides, mainly $\beta$-glucans and chitin, proteins and glycoproteins, generally known as mannoproteins, and other minor components. Cell wall proteins $(\mathrm{CWP})$ are either covalently linked to the cell wall $\beta(1,6)$-glucans by a glycophosphatidylinositol (GPI) moiety or linked via an alkali sensitive linkage to $\beta(1,3)$-glucans. The sugar moieties in CWP are $N$ - and/or $O$ - linked to the protein core [74]. Despite the importance of those components, little is known about the surface protein composition of S. schenckii and S. brasiliensis.

\section{a) Adhesins and/or cell surface proteins}

Previous studies searching for adhesins and antigens in cell extracts of Sporothrix demonstrated the presence of a main antigen on both species, known as Gp70, a secreted antigen that is also present on the cell surface acting as an adhesin [75-77]. The genomes of S. schenckii and S. brasiliensis were investigated with different predictors to ascertain the presence of these cell wall components.

An in silico comparative analysis was performed in order to determine the putative adhesins and/or cell surface proteins bearing a GPI-anchor. According to ProFASTA and FungalRV, S. schenckii harbors 68 and 61 surface proteins, respectively, that have adhesin properties $(\mathrm{n}=129)$. Of these, 12 were found by both predictors (Additional file 11: Figure S9A, Additional file 2: Table S6) totalizing 117 unique predicted proteins in the cell wall of S. schenckii. For S. brasiliensis we have identified 54 and 
63 cell wall proteins $(n=117)$, respectively, 11 of which were predicted by both algorithms. For this species, a total of 106 unique predicted proteins (Additional file 11: Figure S9B, Additional file 2: Table S7). The protein sequence relative to the previously proven cell surface/ adhesin Gp70 was not predicted to possess this function or to be present in the surface location by any of the predictors used [77]. Previous studies described several other important, non-classical surface proteins present in other fungi but which were not recognized in Sporothrix by FungalRV and ProFASTA [78-80]. The major classes of proteins predicted in S. schenckii and S. brasiliensis, by both ProFASTA and FungalRV, are currently annotated either as hypothetical proteins or belonging to a protein family with unknown function (Figure 9). This indicates that proteomic studies are needed to validate the expression of such proteins and biochemical functional studies are necessary to clarify their role on the fungal cell surface. The cell wall proteins and/or adhesins predicted for these species were blasted against 11 fungi for comparative analysis, and each protein was blasted against the two Sporothrix species (Additional file 10: Table S8). Eight proteins were found exclusively in S. brasiliensis and eight proteins were present only in S. schenckii. Sixteen Sporothrix-specific proteins were annotated as hypothetical proteins. None of the proteins described are specific to the group of human pathogenic fungi, but interestingly there are some proteins putatively present in the cell wall of Sporothrix that share homology with those of plant and insect-associated fungi.

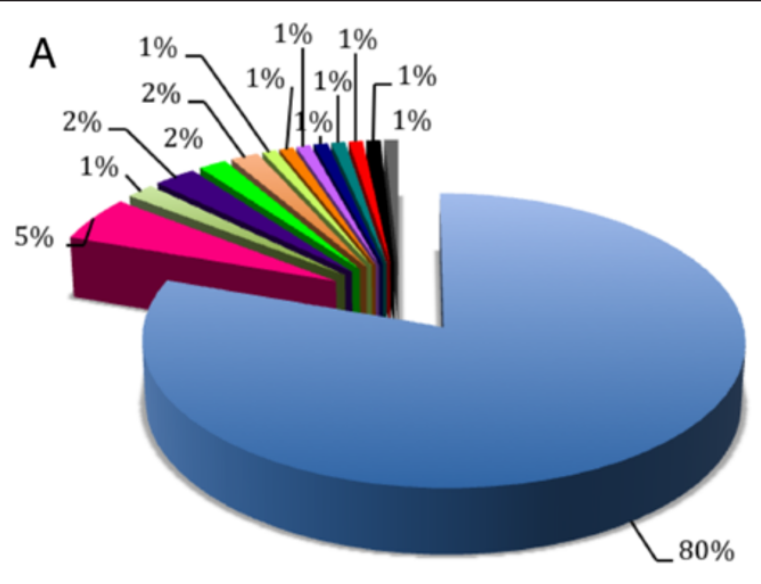

=Uncharacterized

- Cell wall maintenance

= Signaling

- Carbohydrate Processing

- Proteolysis

- Lipase

Phosphatase

Nucleotidase

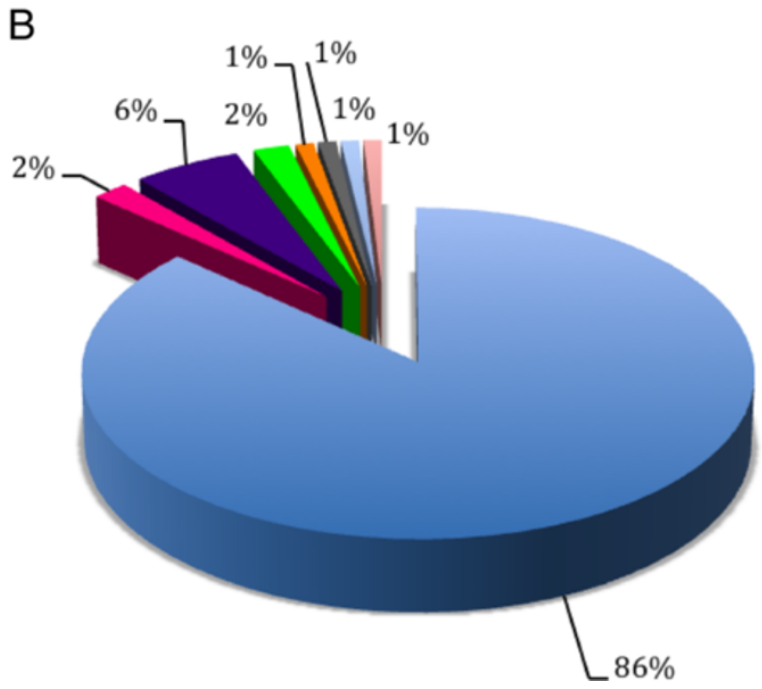

- Uncharacterized

- Cell wall maintenance

- Carbohydrate Processing

- Proteolysis

Nucleotidase

- Redox homeostasis

- Hydrolase

ATPase-stabilizing factor

Figure 9 Putative adhesins identified and/or cell wall GPI-anchored proteins in S. schenckii (A) and S. brasiliensis (B) predicted by ProFASTA and FungalRV. Putative adhesins were classified by their biological function using Gene Ontology (GO) and InterPro databases. 


\section{b) Glucan and chitin metabolism}

In $S$. schenckii, $\beta$-glucans are major components of the cell wall $[81,82]$, and are present as alkali-insoluble and alkali-soluble glucans, containing predominantly $\beta$ $(1,3)$-linkages in both cases [82]. In S. schenckii, no genes related to the synthesis or degradation of $\beta$ glucans have been reported to date. Genomic data analysis revealed a single $F K S$ ortholog in S. schenckii and $S$. brasiliensis genomes, as well as single orthologs in the genomes of the other 14 fungal species studied here (Additional file 11: Table S9). No genes related to the synthesis of either $\beta-1,6$ - or $\beta$-1,4-glucans were identified, although hydrolase orthologs for the three types of $\beta$-glucan linkages in the S. schenckii cell wall, are present in both genomes (Additional file 11: Table S9).

Chitin synthesis in fungi is a rather complex process, regulated by multigene families encoding chitin synthase isoenzymes, whose activities may be spatially regulated to fulfill the multitude of roles ascribed to them [83]. Based on differences in regions of high sequence conservation, chitin synthases have been attributed to seven classes $[83,84]$, whose functional implications are not yet clear in all cases. Despite the low chitin content reported for $S$. schenckii [81], genomic analysis showed the presence of seven CHS genes, in S. schenckii as well as in $S$. brasiliensis genomes. A cluster analysis of their putative products, including 36 fungal chitin synthases, revealed that each of the translation products of the seven CHS Sporothrix genes identified in genomic databases (CHS1 to CHS7), could be ascribed to each of the seven chitin synthase classes known (I to VII) (Additional file 12: Figure S10, Additional file 2: Table S10). It is worth noting that class III chitin synthases were thought to occurr exclusively in filamentous fungi [85]. In our analysis, genes for class III chitin synthases were found in the Sporothrix genomes as well as the genomes of other dimorphic fungi (Additional file 2: Table S10), an indication that class III fungal chitin synthases might be more widespread in fungi. Another interesting finding was the head-to-head arrangement in the S. schenckii and S. brasiliensis genomes of the CHS4 and CHS5 genes, whose putative translated products are class $\mathrm{V}$ and VII chitin synthases (Additional file 8: Figure S6, Additional file 2: Table S10). A similar arrangement was reported for genes coding for classes V and VII of chitin synthases in $P$. brasiliensis, A. nidulans, C. posadasii and $F$. oxysporum [84,86-88]. The meaning of such arrangement is unclear, although a common transcriptional regulation for these genes has been suggested for A. nidulans and $P$. brasiliensis $[84,88,89]$. In agreement with the large number of CHS genes in the Sporothrix genomes, genomic analysis showed the presence of ten and nine chitinase genes, respectively, in the $S$. schenckii and S. brasiliensis genomes (Additional file 2: Table S10).
Polysaccharide synthesis and hydrolysis-related genes identified in S. schenckii and S. brasiliensis genomes correlate with the biochemical composition of the cell wall as reported by Previato et al. [81,82]. It remains to be determined which individual synthase and/or hydrolase gene might be involved in shaping the yeast, mycelial and spore (conidial) walls of Sporothrix species, or even whether any of them might have any role in survival and would provide potential targets for the development of specific antifungal drugs.

\section{c) Protein glycosylation}

Glycoproteins are key components of the S. schenckii cell wall, but thus far little is known about their biosynthetic pathways $[23,24]$. The genomes of S. schenckii and $S$. brasiliensis contained the orthologs involved in elaboration of the $N$-linked glycan core, its transference to proteins and in early trimming. These genes are also known to be involved in glycoprotein endoplasmic reticulum-associated degradation, a quality control system for proteins synthesized within the secretory pathway [90-92] (Additional file 2: Table S11). Furthermore, the genomes contain the putative orthologs encoding Golgi-resident glycosidases and glycosyltransferases that further modify $N$-linked glycans, generating both hybrid and complex $N$-linked glycans. The presence of a gene with significant similarity to those encoding the $\mathrm{N}$ acetylglucosaminidase III (Additional file 2: Table S11), which adds the bisecting GlcNAc residue found in both hybrid and complex $N$-linked glycans [93], suggests an ability to elaborate more complex oligosaccharides than those found in S. cerevisiae [94]. Moreover, our analysis revealed genes encoding putative Golgi UDP-galactose and CMP-sialic acid transporters, suggesting the ability of these fungi to add these sugars to their glycans. S. schenckii and S. brasiliensis also contain an ortholog of $A$. nidulans ugmA, whose product generates the galactomannan-building sugar donor [95], and some putative galactosyltransferases (Additional file 2: Table S12). However, it remains to be addressed whether these enzymes participate in elaboration of glycoproteins and/ or glycolipids. Sialic acid has previously been reported as a component of S. schenckii cell wall glycolipids [96], so it is likely that the putative Golgi CMP-sialic acid transporter is involved in modification of such lipids.

The biosynthetic pathway for O-linked glycans can also be predicted from the analysis of S. schenckii and S. brasiliensis genomes (Additional file 2: Table S13). Optimal characterization of $\mathrm{O}$-linked glycans is via isolation from peptide-rhamnomannans [97]. They contain an $\alpha 1,2$.mannobiose core, an $\alpha 1,2$-glucuronic acid unit, and one or two rhamnose residues. The $S$. schenckii and $S$. brasiliensis genomes contain three putative glucuronosyl transferases that might participate in the elaboration of 
this O-linked glycan (Additional file 2: Table S13). Our genomic analysis could not find any obvious ortholog for rhamnosyl transferases, but Sporothrix contains all the required genes for synthesis of UDP-L-rhamnose (Additional file 2: Table S13) $[98,99]$, the sugar donor in the enzyme reaction catalyzed by rhamnosyltransferases [100]. Synthesis of GPI is quite conserved in eukaryotic cells and the Sporothrix genome contains all genes to elaborate this glycolipid (Additional file 2: Table S14).

\section{Melanin metabolism}

Melanins are dark pigments formed by phenolic and indolic oxidation. These biopolymers are produced by a wide range of organisms, possibly contributing to the maintenance of several species throughout evolution [101]. In fungi, the expression of these pigments has been associated with virulence [102]. Fungi may synthesize melanin by several pathways: in pathogenic fungi, most commonly from endogenous substrate via the 1,8-dihydroxynaphthalene (DHN) pathway or the L-3,4-dihydroxyphenylalanine (L-DOPA) pathways [102]. The latter type is prevalent in Basidiomycetes. However, evidence of both pathways has been found in S. schenckii by means of specific substrate supplementation or drug-related inhibition of the respective pathways [22,23,103,104].

Melanins are found in S. schenckii spores and yeast cells and are produced in vitro and during infection using hamsters as host model. Its detection has also been confirmed by immunofluorescence with monoclonal antibodies raised against $S$. schenckii melanin [21,22]. In $S$. schenckii, melanin pigments can protect the fungus from the mammalian host's innate immune responses providing resistance to killing by phagocytosis and oxidizing agents $[22,105]$. Recently it was reported that S. schenckii and $S$. brasiliensis also produce pyomelanin, a melanoid pigment derived from the degradation of L-tyrosine via a 4-hydroxyphenylpyruvate dioxygenase [103].

Genomic comparison showed that both S. schenckii and $S$. brasiliensis possess enzymes with central roles in melanin synthesis via DHN and DOPA pathways, and also in pyomelanin synthesis. Sporothrix schenckii and S. brasiliensis loci which are postulated to be involved in the melanin biosynthesis pathway are described in Additional file 2: Table S15. We found 19 loci related to melanin biosynthesis in S. schenckii and 17 in S. brasiliensis. Homology with previously described melaninrelated enzymes found in the sequence analyses are: pigment biosynthesis protein yellowish-green 1 , polyketide synthase I and III, tetrahydroxynaphthalene/trihydroxinaphtalene reductase, scytalone dehydratase, laccase, tyrosinase and 4-hydroxyphenylpyruvate dioxygenase, as illustrated in Additional file 13: Figure S11. The multiple functions of melanin in a cell and, especially, the resistance to antifungal drugs and survival of the host immune system, are a strong motivation for the study of the genetic characteristics of melanin biosythesis.

\section{Conclusions}

In this study we provide high quality genomic sequence assemblies and annotations for S. schenckii and S. brasiliensis. Genomic analyses showed a convergent evolutionary fate compared to other dimorphic fungi, even though Sporothrix is a close relative of plant-associated Sordariomycetes. Similar to other dimorphic fungal pathogens we have observed a lack of polysaccharide lyase genes which are associated with decay of plants, suggesting evolutionary adaptations from a plant pathogenic or saprobic to an animal pathogenic life style. In addition, convergent branches linking Sporothrix and other pathogenic dimorphic fungi were also observed in genes involved in signal transduction and secondary metabolism which suggest similar evolutionary traits. The recent hypothesis of habitat shift from a saprobic life style in fermented plant material to mammal transmission may explain numerous plant/related atavisms. Comparative genomics reveals a certain degree of specialization in the Sporothrix lineage which may contribute to our understanding of how fungal-environment-human interactions lead to the selection of pathogenic phenotypes of these species. The Sporothrix system may bring new opportunities for functional studies in order to understand the biology of fungi and infection.

\section{Methods}

\section{Fungal strains and DNA extraction}

Sporothrix schenckii strain 1099-18 (ATCC MYA-4821) was originally obtained from the Mycology Section, Department of Dermatology, Columbia University, New York, isolated from a patient manifesting subcutaneous sporotrichosis, and has been widely used in experiments of cell wall composition and virulence studies in mice models $[97,106]$. Sporothrix brasiliensis strain 5110 (ATCC MYA-4823) was isolated from a feline skin lesion in the epidemic area of sporotrichosis in Rio de Janeiro, Brazil, presenting high virulence in mouse model [77]. Mycelial cells were cultivated in Sabouraud broth at $25^{\circ} \mathrm{C}$, with shaking (150 rpm) for 14 days, collected by centrifugation and washed 3 times with Phosphate-buffered saline (PBS) solution. Cells were disrupted using the Precellys ${ }^{\oplus} 24$ Dual (Bioamerica) with help of CK28 hard tissue homogenizing tubes. DNA extraction was performed using Qiagen DNeasy Plant Mini Kit, according to manufacturer's protocols.

\section{Genome sequencing and assembly}

Sporothrix schenckii and S. brasiliensis genomes were sequenced using next generation 454 pyrosequencing (Roche). Shotgun and paired-end $3 \mathrm{~kb}$ inserts libraries 
were constructed and sequenced in the 454 GS FLX platform according to Roche's protocols at the Computational Genomics Unity of the National Laboratory for Scientific Computing (LNCC, Petrópolis, RJ, Brazil). Genomic assemblies were carried out using Newbler and Celera Assembler. Sequence gap filling and the removal of contigs corresponding to rDNA genes were manually done, decreasing the numbers of scaffolds and contigs. The assembled scaffolds generated by the two species were aligned and oriented using MAUVE [107]. Similarity scores and dot-plot graphs were generated using LALING/PLALING (http://fasta.bioch.virginia.edu/fasta www2/fasta_www.cgi?rm=lalign).

\section{$A b$ initio Gene prediction, annotation and protein family classification}

Gene predictions were performed using three different approaches: SNAP [108], AUGUSTUS [109] and EXONERATE [110] using ORF's identified in the G. clavigera strain kw1407/UAMH 11150 [26] as reference and for training and genomic comparisons. Proteins deduced for G. clavigera proteome were aligned to the S. brasiliensis and $S$. schenckii assembled genomes using Exonerate (percent threshold equal 50) with the model protein2genome. Gene predictions (SNAP and AUGUSTUS) and protein (EXONERATE) alignments were used as input in order to identify consensus gene structures using EVidenceModeler [111]. Consensus ORF's were subjected to Blast searches against NCBI refseq_protein, KEGG and SwissProt databases. Automatic annotations were performed using SABIA - upgraded for eukaryotic organisms [112] and validated ORF's were considered with minimum query/subject coverage of $60 \%$ and minimum positive $50 \%$. In addition, gene categories according KEGG were inspected manually in order to re-assemble the metabolic pathways of S. brasiliensis and S. schenckii. Alignments were made by Blastp and the lowest e-value was used to consider homologous sequences. Next, loci identified in S. schenckii and S. brasiliensis genomes were blasted against the genome libraries of 14 selected fungi (Neurospora crassa, Aspergillus nidulans, A. fumigatus, Talaromyces marneffei, Paracoccidioides lutzii, P. brasiliensis, Coccidioides immitis, Blastomyces dermatitidis, Histoplasma capsulatum, Fusarium graminearum, Magnaporthe oryzae, Sordaria macrospora, Verticillium dahliae, Grosmannia clavigera) to infer the putative orthologues. Gene products were categorized according to biological process, cellular component and molecular function using GeneOntology (GO) using Blast2GO. Secreted proteins were identified using SignalP3.0 (http://www.cbs.dtu.dk/services/SignalP/) using hidden Markov model.

The prediction of mobile genetic entities was performed by similarity searches using the following approaches and databases: a) Nucleotide Blast against Repbase version 17.10 (http://www.girinst.org/repbase/) [113], Dfam database version 1.1 [114] and Gypsy database version 2.0 (GyDB) [115]; b) PSI-BLAST (Position-Specific Iterated BLAST) using profiles of proteins corresponding to major clades/families of Transposable Elements (TEs) implemented with TransposonPSI tool (http://transposonpsi. sourceforge.net/); c) reverse position-specific BLAST algorithm (RPSBLAST) against Conserved Domain Database (CDD) version March 2013 [116]; and d) tblastn taking specific protein subsets against the Sporothrix genome. These subsets were built from NCBI Non Redundant (NR) database version March 2011 using particular description terms related to transposable elements including (apurinic/ apyrimidinic endonuclease, aspartic proteinase, ATPase, endonuclease, envelope, GAG protein, helicase, integrase, polymerase $\mathrm{B}$, replication protein $\mathrm{A}$, reverse transcriptase, RNase, transposase, tyrosine transposase/recombinase). In addition, the Tandem repeat finder (TRF) algorithm was used for finding tandem repeats [117]. Transposable elements were classified accordingly [118]. All results were obtained using locally compiled databases. Perl scripts were built for automation of genome scans, report generation and data integration. Artemis sequence visualization and annotation tool [119] was used for manual curation and annotation of transposable elements.

Whole genome gene families were identified using InterproScan combined with Pfam domain assignments. Annotation of carbohydrate-active enzymes was performed in a two-step procedure where the translated protein sequences were compared to the full length sequences derived from the Carbohydrate-Active enZymes (CAZy) database (www.cazy.org; [120]) using BLAST [121]. The query sequences that had an e-value $<0.1$ were subjected to a BLAST search against sequence fragments corresponding to individual catalytic and carbohydrate-binding modules described in CAZy, along with a HMMer search [122] using hidden Markov models corresponding to each CAZy module family. A family assignment was considered reliable when the two methods gave the same result. Borderline cases were resolved by inspection of conserved features such as the presence of known catalytic residues.

\section{Gene family expansion and contractions}

Gene families were determined using OrthoMCL approach comparing with other 13 fungi (Additional file 2: Table S1). Domains were annotated for each orthologous cluster using Interpro [123], Pfam [124] and SMART [125] databases. Significant enrichment or depletion of domains in the Sporothrix lineage were calculated based on hypergeometric comparisons $(\mathrm{P}<0.05)$ and the reported $\mathrm{p}$-values are adjusted for multiple testing using q-value [126,127]. The expanded families with 
highest discrepancies between Sporothrix and other compared fungi were individually analyzed. Protein sequences of LysM, PKS enoyl reductase, Ras, Rab and Rho small gtpases we individually aligned using ClustalW [128] and the domains were manually checked. Uninformative positions of the alignment were eliminated using trimal [129] and the best-fit protein substitution model was inferred based on likelihood values under AIC criteria, implemented in ProtTest [130]. Phylogenetic analysis of expanded gene families were carried out using Maximum likelihood methods implemented in PhyML 3.0 software and 1.000 of non-parametric bootstraps were tested for branch support [131]. Gene duplications/losses for the given family trees were inferred using Notung 2.6 software [132].

\section{Blast reciprocal best hit and phylogenomic analysis}

Bidirectinoal-best Blast Hit $(\mathrm{BBH})$ were performed using two different datasets: first we performed the comparisons between S. schenckii, S. brasiliensis and G. clavigera genomes in order to identify the unique genes in Sporothrix lineage. In addition, Blast reciprocal best hits were performed to identify common orthologues in 25 fungal genomes (Additional file 2: Table S1) using minimum query/subject coverage of $50 \%$ and e-value of $E \leq 1 \times 10^{-20}$. A total of 395 orthologs were found in all species analyzed and were aligned using MAFFT [133] and retrieved alignments were trimmed using Trimal [129] in order to exclude spurious sequences or poorly aligned regions. Phylogenomic analysis was performed using RAxML [134] and the Dayhoff aminoacid substitution model was selected according ProtTest [130]. Divergence time between species was calculated with help of $\mathrm{r} 8 \mathrm{~s}$ v 1.8 [135] program using Langley-Fitch model [136] considering the origin of the Ascomycota at 500 to 650 MYA (Millions Years Ago) [137].

\section{Cell wall protein/adhesin analysis}

Two programs were used for the prediction of cell wall proteins/adhesins: ProFASTA [138] and FungalRV [139]. Analysis using the fasta files of the complete genomes of S. schenckii and S. brasiliensis were performed for prediction of GPI-anchor secretion signal and transmembrane domain identification. The SignalP 4.0 server (http://www. cbs.dtu.dk/services/SignalP/) was applied for prediction of the presence and location of signal peptide cleavage sites in amino acid sequences, using the method of Input sequences, which do not include TM regions. Then, the TMHMM Server v. 2.0 (http://www.cbs.dtu. $\mathrm{dk} /$ services/TMHMM/) was used for prediction of transmembrane helices in proteins, and finally the Big-PI fungal predictor [140] was used for GPI modification sites. The ProFASTA requires the combination of these three analyses to prospect cell wall proteins and adhesins, with the following parameters: SignalIP 4.0 positive; TMHMM $2.0<1$ helices and number of AA to exclude as 45 from $\mathrm{N}$-terminus and 35 for C-terminus; Big-PI positive. The FungalRV validates only proteins with score up to 0.5 for adhesin or adhesin-like features.

\section{Autophagy, peroxisome and endocytosis}

The initial tool used for this annotation was the KEGG automatic classification, which adequately identified genes involved in peroxisome biogenesis. However, the automatic annotation algorithms only picked up a few genes involved in autophagosome biogenesis and endocytosis, so different approaches were necessary. For the genes involved in autophagy, we started by collecting on the SGD all protein sequences annotated as involved in autophagy and autophagosome biogenesis in Saccharomyces cerevisiae. All of these sequences were blasted against the $S$. schenckii and S. brasiliensis databases in order to correctly identify homologous protein sequences. To narrow down the list, we focused the analysis on 17 genes that are necessary for autophagosome biogenesis in yeast [141] plus those that are shown on KEGG. Regarding endocytosis, the KEGG table only showed two genes involved in the process itself and several genes involved in vacuolar degradation. To overcome this limitation, the genes that were used for annotation were those listed in a review article as being involved in clathrin-mediated endocytosis in S. cerevisiae [142]. All protein sequences encoded by these genes were blasted against the S. schenckii and S. brasiliensis databases.

\section{Availability of supporting data}

The data sets supporting the results of this article are included within the article and its additional files.

\section{Additional files}

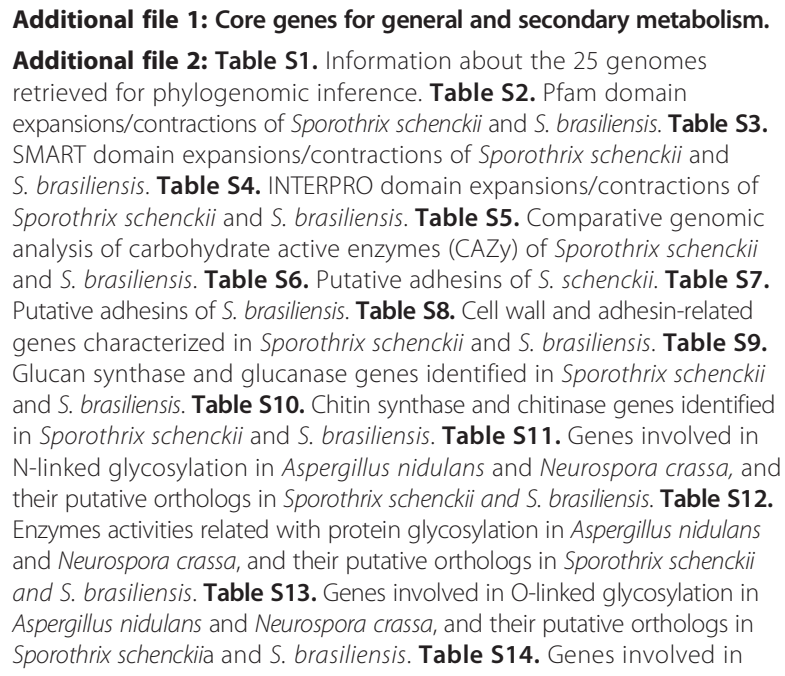


GPI-anchor elaboration in Aspergillus nidulans and Neurospora crassa and their putative orthologs in Sporothrix schenckii and S. brasiliensis. Table S15. Melanin biosynthesis pathway and putative orthologs in Sporothrix schenckii and S. brasiliensis. Table S16. Comparative analysis of core genes related to amino acids, Secondary, Energy, Cofactor and Vitamin metabolisms of Sporothrix schenckii and S. brasiliensis. Table S17. Genomic identification and classification of phospholipases A, C, and D enzyme families in Sporothrix schenckii and S. brasiliensis genomes. Table S18. Homologs of vitamin and cofactor genes presented analyzed by FUNGlpath in both Sporothrix species. Table S19. Orthologous genes related to catabolism and transport in Sporothrix schenckii and S. brasiliensis.

Additional file 3: Figure S2. Phylogenetic distribution of LysM domains containing proteins in Sporothrix. The LysM domains are displayed along the taxa (red bars), chitin binding module type 1 (CB1) (blue bars) plus catalytic sites identified (glycoside hydrolase - GH or Pectin Lyase - PL). Gene paralogous duplications are highlighted by red boxes.

Additional file 4: Figure S3. Unrooted maximum likelihood tree of Ras Small GTPase proteins (IPR020849) family shows high diversification in the Sporothrix lineage. Clades harboring Sporothrix and dimorphic fungi are highlighted in red.

Additional file 5: Figure S4. Unrooted maximum likelihood tree of Rho Small GTPase proteins (IPR003578) family shows high diversification in the Sporothrix lineage. Clades harboring Sporothrix and dimorphic fungi are highlighted in red.

Additional file 6: Figure S1. Gene tree and species tree reconciliation of LysM domain-containing genes showing specific Sporothrix duplications (blue boxes).

Additional file 7: Figure S5. Unrooted maximum likelihood tree of Rab Small GTPase proteins (IPR003579) family shows high diversification in the Sporothrix lineage. Clades harboring Sporothrix and dimorphic fungi are highlighted in red.

Additional file 8: Figure S6. Gene tree and species tree reconciliation of small GTPase Ras gene family showing independent gene losses in other species and the increased copy number in Sporothrix (blue boxes)

Additional file 9: Figure S7. Gene tree and species tree reconciliation of small GTPase Rho gene family showing independent gene losses in other species and the increased copy number in Sporothrix (blue boxes).

Additional file 10: Figure S8. Gene tree and species tree reconciliation of small GTPase Rab gene family showing independent gene losses in other species and the increased copy number in Sporothrix (blue boxes).

Additional file 11: Figure S9. Chart pies showing the efficiency of the algorithms used to predict the putative adhesins and/or cell wall GPI-anchored proteins of (A) S. schenckii $(n=118)$ and (B) S. brasiliensis $(n=106)$. The relative percentage of putative adhesins and/or GPI- anchored proteins, predicted by either ProFASTA or Fungal RV, is shown as well as the proteins in common by both predictors.

Additional file 12: Figure S10. Phylogenetic tree of relatedness of Sporothrix spp. chitin synthases. The Mega 4 software package was employed, using ClustalW for sequence alignment. Construction of the phylogenetic tree was done by the neighbor-joining method using 1000 replications. The seven chitin synthases identified for both, Sporothrix brasiliensis and $\mathrm{S}$. schenckii, cluster within the seven chitin synthase classes (I to VII) previously reported [83]. GenBank accession numbers of sequences, and names of fungal species used for construction of the tree are displayed in Additional file 12: Table S10

Additional file 13: Figure S11. Melanin biosynthesis pathways for DHN-Melanin, DOPA-melanin and pyomelanin proposed for S. schenckii and $\mathrm{S}$. brasiliensis based on melanin biosynthetic pathways described in other pathogenic fungi. The putative enzymes identified in the genomes of S. schenckii and S. brasiliensis are indicated in circles. Locus tags, Gene products, numbers of exons, size of transcripts, estimated protein sizes and current annotations are listed.

\section{Competing interests}

The authors declare that they have no competing interests.

\section{Authors' contributions}

Designed the experiments: MMT LGPA RCS JCR JFS BH HMMM SRA JES GAN PSC LMLB ATRV MSSF; Sequencing, assembling and annotation: MMT LGPA PK FLA ESK AKRA LF LSD KSF RCS JCR NCA HCP AMN PA ALG VPM LDFP AV CBC PAS OLC FFMO TCS ALNB MAS LMO MMM HV MMLC BH HMMM JES; Comparative genomics analysis: MMT LGPA PK FLA ESK AKRA LF LSD KSF RCS JCR NCA HCP AMN PA ALG VPM LDFP AV CBC PAS OLC FFMO TCS ALNB MAS LMO MMM HV MMLC SH BH HMMM JES; Contributed to analysis tools: MMT BH GAN PSC HMMM SRA JES LMLB ATRV MSSF; Wrote the manuscript: MMT MSSF. All authors read and approved the final manuscript.

\section{Acknowledgments}

We are grateful to FAP-DF, CNPq and Capes for the financial support and fellowships of the projects Pronex (grant number 193000569/2009) and Genoprot (grant number 559572/2009-3). HMMM is supported by CONACyT, México (grant number CB2011-166860). BH is an Honorary Professor of Glycomics at the Faculty of Health and Medical Sciences, University of Copenhagen, Denmark.

\section{Author details}

'Departamento de Biologia Celular, Universidade de Brasília, Brasília, DF, Brazil. ${ }^{2}$ Laboratório Nacional de Computação Científica, Petrópolis, RJ, Brazil. ${ }^{3}$ Departamento de Biologia Celular, Instituto de Biologia Roberto Alcântara Gomes, Universidade do Estado do Rio de Janeiro, Rio de Janeiro, RJ, Brazil. ${ }^{4}$ Departamento de Microbiologia, Universidade Federal de Minas Gerais, Belo Horizonte, MG, Brazil. ${ }^{5}$ Grupo Informática de Biossistemas, Centro de Pesquisas René Rachou, FIOCRUZ, Minas, Belo Horizonte, MG, Brazil. ${ }^{6}$ Departamento de Análises Clínicas, Universidade Estadual de Maringá, Maringá, PR, Brazil. 'Programa de Pós-Graduação em Ciências e Tecnologias em Saúde, Universidade de Brasília, Ceilândia, Brasília, DF, Brazil. ${ }^{8}$ Instituto de Ciências Ambientais, Químicas e Farmacêuticas, Universidade Federal de São Paulo, Campus Diadema, São Paulo, SP, Brazil. ${ }^{9}$ Pós-Graduação em Ciências Genômicas e Biotecnologia, Universidade Católica de Brasília, Brasília, DF, Brazil. ${ }^{10}$ Programa de pós-graduação em Medicina Tropical, Universidade de Brasília, Brasília, DF, Brazil. "Programa de pós-graduação em Bioinformática, Universidade Federal de Minas Gerais, Minas Gerais, Brazil. ${ }^{12}$ Departamento de Microbiologia Imunobiologia e Parasitologia, Universidade Federal de São Paulo, São Paulo, SP, Brazil. ${ }^{13}$ Centro de Microbiología y Biología Celular, Instituto Venezolano de Investigaciones Cientificas, Caracas, Venezuela. ${ }^{14}$ CBS-KNAW Fungal Biodiversity Centre, Utrecht, The Netherlands. ${ }^{15}$ Centre National de la Recherche Scientifique, Aix-Marseille, Université, CNRS, Marseille, France. ${ }^{16}$ Departamento de Biología, Universidad de Guanajuato, Guanajuato, Mexico. ${ }^{17}$ Departamento de Análises Clínicas e Toxicológicas, Universidade de São Paulo, São Paulo, SP, Brazil. ${ }^{18}$ Department of Plant Pathology \& Microbiology, University of California, Riverside, CA, USA.

Received: 11 February 2014 Accepted: 25 September 2014 Published: 29 October 2014

\section{References}

1. Marimon R, Cano J, Gene J, Sutton DA, Kawasaki M, Guarro J: Sporothrix brasiliensis, S. globosa, and S. mexicana, three new Sporothrix species of clinical interest. J Clin Microbiol 2007, 45(10):3198-3206.

2. Rodrigues AM, de Hoog S, de Camargo ZP: Emergence of pathogenicity in the Sporothrix schenckii complex. Med Mycol: Offic Publ Int Soc Hum Anim Mycol 2013, 51(4):405-412.

3. Silva-Vergara ML, de Camargo ZP, Silva PF, Abdalla MR, Sgarbieri RN Rodrigues AM, dos Santos KC, Barata CH, Ferreira-Paim K: Disseminated Sporothrix brasiliensis infection with endocardial and ocular involvement in an HIV-infected patient. Am J Trop Med Hyg 2012, 86(3):477-480.

4. Rosane Orofino-Costa NU, Alexandre Carlos G, de Macedo PM, Arles B, Emylli D, de Melo Teixeira M, Maria Sueli F, Bernardes-Engemann AR, Leila Maria L-B: Pulmonary cavitation and skin lesions mimicking tuberculosis in a HIV negative patient caused by Sporothrix brasiliensis. Med Mycol Case Rep 2013, 2:7.

5. Oliveira MM, Almeida-Paes R, Muniz MM, Gutierrez-Galhardo MC, ZancopeOliveira RM: Phenotypic and molecular identification of Sporothrix isolates from an epidemic area of sporotrichosis in Brazil. Mycopathologia 2011, 172(4):257-267.

6. Rodrigues AM, de Melo TM, de Hoog GS, Schubach TM, Pereira SA, Fernandes GF, Bezerra LM, Felipe MS, de Camargo ZP: Phylogenetic 
analysis reveals a high prevalence of Sporothrix brasiliensis in feline sporotrichosis outbreaks. PLoS Negl Trop Dis 2013, 7(6):e2281.

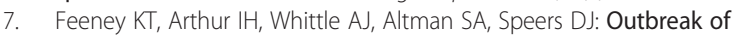
sporotrichosis, Western Australia. Emerg Infect Dis 2007, 13(8):1228-1231.

8. Song Y, Yao L, Zhong SX, Tian YP, LiU YY, Li SS: Infant sporotrichosis in northeast China: a report of 15 cases. Int J Dermatol 2011, 50(5):522-529.

9. Sivagnanam S, Bannan AM, Chen SC, Ralph AP: Sporotrichosis (Sporothrix schenckii infection) in the New South Wales mid-north coast, 2000-2010. Med J Aust 2012, 196(9):588-590.

10. Verma S, Verma GK, Singh G, Kanga A, Shanker V, Singh D, Gupta P, Mokta K, Sharma V: Sporotrichosis in sub-himalayan India. PLoS Negl Trop Dis 2012, 6(6):e1673.

11. Lopes-Bezerra LM, Schubach A, Costa RO: Sporothrix schenckii and sporotrichosis. An Acad Bras Cienc 2006, 78(2):293-308.

12. Travassos LR, Lloyd KO: Sporothrix schenckii and related species of Ceratocystis. Microbiol Rev 1980, 44(4):683-721

13. Klein BS, Tebbets B: Dimorphism and virulence in fungi. Curr Opin Microbiol 2007, 10(4):314-319

14. Rappleye CA, Goldman WE: Defining virulence genes in the dimorphic fungi. Annu Rev Microbiol 2006, 60:281-303.

15. de Beer ZW, Harrington TC, Vismer HF, Wingfield BD, Wingfield M: Phylogeny of the Ophiostoma stenoceras-Sporothrix schenckii complex. Mycologia 2003, 95(3):434-441.

16. Nemecek JC, Wuthrich M, Klein BS: Global control of dimorphism and virulence in fungi. Science 2006, 312(5773):583-588.

17. Hou B, Zhang Z, Zheng F, Liu X: Molecular cloning, characterization and differential expression of DRK1 in Sporothrix schenckii. Int J Mol Med 2013, 31(1):99-104

18. Latge JP: Tasting the fungal cell wall. Cell Microbiol 2010, 12(7):863-872.

19. Lopes-Bezerra L: Sporothrix schenckii cell wall peptidorhamnomannans. Front Microbio/ 2011, 2:243.

20. Lopez-Romero E, Reyes-Montes Mdel R, Perez-Torres A, Ruiz-Baca E, Villagomez-Castro JC, Mora-Montes HM, Flores-Carreon A, Toriello C Sporothrix schenckii complex and sporotrichosis, an emerging health problem. Future Microbiol 2011, 6(1):85-102

21. Morris-Jones R, Youngchim S, Gomez BL, Aisen P, Hay RJ, Nosanchuk JD, Casadevall A, Hamilton AJ: Synthesis of melanin-like pigments by Sporothrix schenckii in vitro and during mammalian infection. Infect Immun 2003, 71(7):4026-4033.

22. Romero-Martinez R, Wheeler M, Guerrero-Plata A, Rico G, Torres-Guerrero H: Biosynthesis and functions of melanin in Sporothrix schenckii. Infect Immun 2000, 68(6):3696-3703.

23. Teixeira PA, De Castro RA, Ferreira FR, Cunha MM, Torres AP, Penha CV, Rozental S, Lopes-Bezerra LM: L-DOPA accessibility in culture medium increases melanin expression and virulence of Sporothrix schenckii yeast cells. Med Mycol: Offic Publ Int Soc Hum Anim Mycol 2010, 48(5):687-695.

24. Zhang Y, Hagen F, Stielow B, Rodrigues AM, Samerpitak K, Xun Z, Feng P, Yang L, Chen M, Deng S, Li S, Liao W, Li R, Li F, Meis JF, Guarro J, Teixeira MM, Al-Zahrani, Camargo ZP, Zhang L, Hoog S: Phylogeography and evolutionary patterns in Sporothrix species with a pathogenic potential for mammals. Persoonia. in press.

25. de Meyer EM, de Beer ZW, Summerbell RC, Moharram AM, de Hoog GS, Vismer HF, Wingfield MJ: Taxonomy and phylogeny of new wood- and soil-inhabiting Sporothrix species in the Ophiostoma stenoceras-Sporothrix schenckii complex. Mycologia 2008, 100(4):647-661.

26. DiGuistini S, Wang Y, Liao NY, Taylor G, Tanguay P, Feau N, Henrissat B, Chan SK, Hesse-Orce U, Alamouti SM, Tsui CK, Docking RT, Levasseur A, Haridas S, Robertson G, Birol I, Holt RA, Marra MA, Hamelin RC, Hirst M, Jones SJ, Bohlmann J, Breuil C: Genome and transcriptome analyses of the mountain pine beetle-fungal symbiont Grosmannia clavigera, a lodgepole pine pathogen. Proc Natl Acad Sci U S A 2011, 108(6):2504-2509.

27. Bentz BJ, Regniere J, Fettig CJ, Hansen EM, Hayes JL, Hicke JA, Kesley RG, Negron JF, Seybold SJ: Climate change and bark beetles of the western United States and Canada: Direct and indirect effects. Bioscience 2010, 60(8):12.

28. Amselem J, Cuomo CA, van Kan JA, Viaud M, Benito EP, Couloux A, Coutinho PM, de Vries RP, Dyer PS, Fillinger S, Fournier E, Gout L, Hahn M, Kohn L, Lapalu N, Plummer KM, Pradier JM, Quevillon E, Sharon A, Simon A, ten Have A, Tudzynski B, Tudzynski P, Wincker P, Andrew M, Anthouard V, Beever RE, Beffa R, Benoit I, Bouzid O, et al: Genomic analysis of the necrotrophic fungal pathogens Sclerotinia sclerotiorum and Botrytis cinerea. PLoS Genet 2011, 7(8):e1002230.

29. Sharpton TJ, Stajich JE, Rounsley SD, Gardner MJ, Wortman JR, Jordar VS, Maiti R, Kodira CD, Neafsey DE, Zeng Q, Hung CY, McMahan C, Muszewska A, Grynberg M, Mandel MA, Kellner EM, Barker BM, Galgiani JN, Orbach MJ, Kirkland TN, Cole GT, Henn MR, Birren BW, Taylor JW: Comparative genomic analyses of the human fungal pathogens Coccidioides and their relatives. Genome Res 2009, 19(10):1722-1731.

30. Theodoro RC, Teixeira Mde M, Felipe MS, Paduan Kdos S, Ribolla PM San-Blas G, Bagagli E: Genus paracoccidioides: species recognition and biogeographic aspects. PLoS One 2012, 7(5):e37694.

31. Ambrosio AB, do Nascimento LC, Oliveira BV, Teixeira PJ, Tiburcio RA, Toledo Thomazella DP, Leme AF, Carazzolle MF, Vidal RO, Mieczkowski P, Meinhardt LW, Pereira GA, Cabrera OG: Global analyses of Ceratocystis cacaofunesta mitochondria: from genome to proteome. BMC Genomics 2013, 14:91.

32. Dujon B: Group I introns as mobile genetic elements: facts and mechanistic speculations-a review. Gene 1989, 82(1):91-114.

33. Cummings DJ, MCNally KL, Domenico JM, Matsuura ET: The complete DNA sequence of the mitochondrial genome of Podospora anserina. Curr Genet 1990, 17(5):375-402

34. Lambowitz AM, Perlman PS: Involvement of aminoacyl-tRNA synthetases and other proteins in group I and group II intron splicing. Trends Biochem Sci 1990, 15(11):440-444.

35. Sethuraman J, Majer A, Friedrich NC, Edgell DR, Hausner G: Genes within genes: multiple LAGLIDADG homing endonucleases target the ribosomal protein S3 gene encoded within an rnl group I intron of Ophiostoma and related taxa. Mol Biol Evol 2009, 26(10):2299-2315.

36. Joardar V, Abrams NF, Hostetler J, Paukstelis PJ, Pakala S, Pakala SB, Zafar N, Abolude OO, Payne G, Andrianopoulos A, Denning DW, Nierman WC: Sequencing of mitochondrial genomes of nine Aspergillus and Penicillium species identifies mobile introns and accessory genes as main sources of genome size variability. BMC Genomics 2012, 13:698

37. Xue M, Yang J, Li Z, Hu S, Yao N, Dean RA, Zhao W, Shen M, Zhang H, Li C, Liu L, Cao L, Xu X, Xing Y, Hsiang T, Zhang Z, Xu JR, Peng YL: Comparative analysis of the genomes of two field isolates of the rice blast fungus Magnaporthe oryzae. PLoS Genet 2012, 8(8):e1002869.

38. Daboussi MJ, Capy P: Transposable elements in filamentous fungi. Annu Rev Microbiol 2003, 57:275-299.

39. Cuomo CA, Guldener U, XU JR, Trail F, Turgeon BG, Di Pietro A, Walton JD, Ma LJ, Baker SE, Rep M, Adam G, Antoniw J, Baldwin T, Calvo S, Chang YL, Decaprio D, Gale LR, Gnerre S, Goswami RS, Hammond-Kosack K, Harris LJ, Hilburn K, Kennell JC, Kroken S, Magnuson JK, Mannhaupt G, Mauceli E, Mewes HW, Mitterbauer R, Muehlbauer G, et al: The Fusarium graminearum genome reveals a link between localized polymorphism and pathogen specialization. Science 2007, 317(5843):1400-1402.

40. Galagan JE, Calvo SE, Borkovich KA, Selker EU, Read ND, Jaffe D, FitzHugh W, Ma LJ, Smirnov S, Purcell S, Rehman B, Elkins T, Engels R, Wang S, Nielsen CB, Butler J, Endrizzi M, Qui D, lanakiev P, Bell-Pedersen D, Nelson MA, Werner-Washburne M, Selitrennikoff CP, Kinsey JA, Braun EL, Zelter A Schulte $U$, Kothe GO, Jedd G, Mewes W, et al: The genome sequence of the filamentous fungus Neurospora crassa. Nature 2003, 422(6934):859-868.

41. Desjardins CA, Champion MD, Holder JW, Muszewska A, Goldberg J, Bailao AM, Brigido MM, Ferreira ME, Garcia AM, Grynberg M, Gujja S, Heiman DI, Henn MR, Kodira CD, Leon-Narvaez H, Longo LV, Ma LJ, Malavazi I, Matsuo AL, Morais FV, Pereira M, Rodriguez-Brito S, Sakthikumar S, Salem-lzacc SM Sykes SM, Teixeira MM, Vallejo MC, Walter ME, Yandava C, Young S, et al: Comparative genomic analysis of human fungal pathogens causing paracoccidioidomycosis. PLoS Genet 2011, 7(10):e1002345.

42. Kubicek CP, Herrera-Estrella A, Seidl-Seiboth V, Martinez DA, Druzhinina IS, Thon M, Zeilinger S, Casas-Flores S, Horwitz BA, Mukherjee PK, Mukherjee M, Kredics L, Alcaraz LD, Aerts A, Antal Z, Atanasova L, Cervantes-Badillo MG, Challacombe J, Chertkov O, McCluskey K, Coulpier F, Deshpande N, von Dohren H, Ebbole DJ, Esquivel-Naranjo EU, Fekete E, Flipphi M, Glaser F, Gomez-Rodriguez EY, Gruber S, et al: Comparative genome sequence analysis underscores mycoparasitism as the ancestral life style of Trichoderma. Genome Biol 2011, 12(4):R40.

43. Teixeira MM, Rodrigues AM, Tsui CK, Almeida LGP, Van Diepeningen AD, Van Den Ende BG, Sovegni GF, Kano R, Hamelin RC, Bezerra LM, Vasconcelos ATR, De Hoog GS, Camargo ZP, Felipe MS: Clonal expansion of a highly virulent mating type in epidemic outbreak of human and feline sporothrichosis. Euk Cell. in press. 
44. Heitman J, Sun S, James TY: Evolution of fungal sexual reproduction. Mycologia 2013, 105(1):1-27.

45. Kraaijeveld K, Zwanenburg B, Hubert B, Vieira C, De Pater S, Van Alphen JJ, Den Dunnen JT, De Knijff P: Transposon proliferation in an asexual parasitoid. Mol Ecol 2012, 21(16):3898-3906.

46. Dolgin ES, Charlesworth B: The fate of transposable elements in asexual populations. Genetics 2006, 174(2):817-827.

47. Forslund K, Sonnhammer EL: Evolution of protein domain architectures. Methods Mol Biol 2012, 856:187-216.

48. Bueter CL, Specht CA, Levitz SM: Innate sensing of chitin and chitosan. PLoS Pathog 2013, 9(1):e1003080.

49. Lee CG, Da Silva CA, Dela Cruz CS, Ahangari F, Ma B, Kang MJ, He CH, Takyar S, Elias JA: Role of chitin and chitinase/chitinase-like proteins in inflammation, tissue remodeling, and injury. Annu Rev Physiol 2011, 73:479-501.

50. Mora-Montes HM, Netea MG, Ferwerda G, Lenardon MD, Brown GD, Mistry AR, Kullberg BJ, O'Callaghan CA, Sheth CC, Odds FC, Brown AJ, Munro CA, Gow NA: Recognition and blocking of innate immunity cells by Candida albicans chitin. Infect Immun 2011, 79(5):1961-1970.

51. Koller B, Muller-Wiefel AS, Rupec R, Korting HC, Ruzicka T: Chitin modulates innate immune responses of keratinocytes. PLoS One 2011, 6(2):e16594.

52. de Jonge $R$, van Esse HP, Kombrink A, Shinya T, Desaki Y, Bours R, van der Krol S, Shibuya N, Joosten MH, Thomma BP: Conserved fungal LysM effector Ecp6 prevents chitin-triggered immunity in plants. Science 2010, 329(5994):953-955.

53. Martinez DA, Oliver BG, Graser Y, Goldberg JM, Li W, Martinez-Rossi NM, Monod M, Shelest E, Barton RC, Birch E, Brakhage AA, Chen Z, Gurr SJ, Heiman D, Heitman J, Kosti I, Rossi A, Saif S, Samalova M, Saunders CW, Shea T, Summerbell RC, Xu J, Young S, Zeng Q, Birren BW, Cuomo CA, White TC: Comparative genome analysis of Trichophyton rubrum and related dermatophytes reveals candidate genes involved in infection. mBio 2012, 3(5):e00259-00212. http://mbio.asm.org/content/3/5/e00259-12.

54. Rojas AM, Fuentes $G$, Rausell $A$, Valencia $A$ : The Ras protein superfamily: evolutionary tree and role of conserved amino acids. J Cell Biol 2012, 196(2):189-201.

55. Alspaugh JA, Cavallo LM, Perfect JR, Heitman J: RAS1 regulates filamentation mating and growth at high temperature of Cryptococcus neoformans. Mol Microbiol 2000, 36(2):352-365.

56. Waugh MS, Nichols CB, DeCesare CM, Cox GM, Heitman J, Alspaugh JA: Ras 1 and Ras2 contribute shared and unique roles in physiology and virulence of Cryptococcus neoformans. Microbiology 2002, 148(Pt 1):191-201.

57. Metz JG, Roessler P, Facciotti D, Levering C, Dittrich F, Lassner M, Valentine R, Lardizabal K, Domergue F, Yamada A, Knauf V, Browse J: Production of polyunsaturated fatty acids by polyketide synthases in both prokaryotes and eukaryotes. Science 2001, 293(5528):290-293.

58. Langfelder K, Jahn B, Gehringer H, Schmidt A, Wanner G, Brakhage AA: Identification of a polyketide synthase gene (pksP) of Aspergillus fumigatus involved in conidial pigment biosynthesis and virulence. Med Microbiol Immunol 1998, 187(2):79-89.

59. Campbell CD, Vederas JC: Biosynthesis of lovastatin and related metabolites formed by fungal iterative PKS enzymes. Biopolymers 2010, 93(9):755-763

60. Keller NP, Turner G, Bennett JW: Fungal secondary metabolism - from biochemistry to genomics. Nat Rev Microbiol 2005, 3(12):937-947.

61. Kroken S, Glass NL, Taylor JW, Yoder OC, Turgeon BG: Phylogenomic analysis of type I polyketide synthase genes in pathogenic and saprobic ascomycetes. Proc Natl Acad Sci U S A 2003, 100(26):15670-15675.

62. Alexander NJ, McCormick SP, Hohn TM: TRI12, a trichothecene efflux pump from Fusarium sporotrichioides: gene isolation and expression in yeast. Mol General Genet: MGG 1999, 261(6):977-984.

63. Soanes DM, Talbot NJ: Comparative genome analysis reveals an absence of leucine-rich repeat pattern-recognition receptor proteins in the kingdom Fungi. PLoS One 2010, 5(9):e12725.

64. Sun $\mathrm{CH}$, McCaffery JM, Reiner DS, Gillin FD: Mining the Giardia lamblia genome for new cyst wall proteins. J Biol Chem 2003, 278(24):21701-21708.

65. Berriman M, Ghedin E, Hertz-Fowler C, Blandin G, Renauld H, Bartholomeu DC, Lennard NJ, Caler E, Hamlin NE, Haas B, Bohme U, Hannick L, Aslett MA, Shallom J, Marcello L, Hou L, Wickstead B, Alsmark UC, Arrowsmith C, Atkin RJ, Barron AJ, Bringaud F, Brooks K, Carrington M, Cherevach I, Chillingworth TJ, Churcher C, Clark LN, Corton CH, Cronin A, et al: The genome of the African trypanosome Trypanosoma brucei. Science 2005, 309(5733):416-422.
66. Lujan HD, Mowatt MR, Conrad JT, Bowers B, Nash TE: Identification of a novel Giardia lamblia cyst wall protein with leucine-rich repeats. Implications for secretory granule formation and protein assembly into the cyst wall. J Biol Chem 1995, 270(49):29307-29313.

67. Deitsch KW, Lukehart SA, Stringer JR: Common strategies for antigenic variation by bacterial, fungal and protozoan pathogens. Nat Rev Microbiol 2009, 7(7):493-503.

68. Jackson AP, Gamble JA, Yeomans T, Moran GP, Saunders D, Harris D, Aslett M, Barrell JF, Butler G, Citiulo F, Coleman DC, de Groot PW, Goodwin TJ, Quail MA, McQuillan J, Munro CA, Pain A, Poulter RT, Rajandream MA, Renauld H, Spiering MJ, Tivey A, Gow NA, Barrell B, Sullivan DJ, Berriman M: Comparative genomics of the fungal pathogens Candida dubliniensis and Candida albicans. Genome Res 2009, 19(12):2231-2244.

69. Freitag M, Williams RL, Kothe GO, Selker EU: A cytosine methyltransferase homologue is essential for repeat-induced point mutation in Neurospora crassa. Proc Natl Acad Sci U S A 2002, 99(13):8802-8807.

70. Horns F, Petit E, Yockteng R, Hood ME: Patterns of repeat-induced point mutation in transposable elements of basidiomycete fungi. Genome Biol Evol 2012, 4(3):240-247.

71. Yonemasu R, McCready SJ, Murray JM, Osman F, Takao M, Yamamoto K, Lehmann AR, Yasui A: Characterization of the alternative excision repair pathway of UV-damaged DNA in Schizosaccharomyces pombe. Nucleic Acids Res 1997, 25(8):1553-1558.

72. Nguyen VQ, Sil A: Temperature-induced switch to the pathogenic yeast form of Histoplasma capsulatum requires Ryp1, a conserved transcriptional regulator. Proc Natl Acad Sci U S A 2008, 105(12):4880-4885.

73. Cain CW, Lohse MB, Homann OR, Sil A, Johnson AD: A conserved transcriptional regulator governs fungal morphology in widely diverged species. Genetics 2012, 190(2):511-521.

74. Duran A, Nombela C: Fungal cell wall biogenesis: building a dynamic interface with the environment. Microbiology 2004, 150(Pt 10):3099-3103.

75. Teixeira PA, de Castro RA, Nascimento RC, Tronchin G, Torres AP, Lazera M, de Almeida SR, Bouchara JP, Penha CV L y, Lopes-Bezerra LM: Cell surface expression of adhesins for fibronectin correlates with virulence in Sporothrix schenckii. Microbiology 2009, 155(Pt 11):3730-3738.

76. Ruiz-Baca E, Toriello C, Perez-Torres A, Sabanero-Lopez M, Villagomez-Castro $J C$, Lopez-Romero E: Isolation and some properties of a glycoprotein of $70 \mathrm{kDa}$ (Gp70) from the cell wall of Sporothrix schenckii involved in fungal adherence to dermal extracellular matrix. Med Mycol: Offic Publ Int Soc Hum Anim Mycol 2009, 47(2):185-196.

77. Castro RA, Kubitschek-Barreira PH, Teixeira PA, Sanches GF, Teixeira MM, Quintella LP, Almeida SR, Costa RO, Camargo ZP, Felipe MS, de Souza W, Lopes-Bezerra LM: Differences in cell morphometry, cell wall topography and Gp70 expression correlate with the virulence of Sporothrix brasiliensis clinical isolates. PLoS One 2013, 8(10):e75656.

78. Albuquerque PC, Nakayasu ES, Rodriques ML, Frases S, Casadevall A, Zancope-Oliveira RM, Almeida IC, Nosanchuk JD: Vesicular transport in Histoplasma capsulatum: an effective mechanism for trans-cell wall transfer of proteins and lipids in ascomycetes. Cell Microbiol 2008, 10(8):1695-1710.

79. Rodrigues ML, Nakayasu ES, Oliveira DL, Nimrichter L, Nosanchuk JD, Almeida IC, Casadevall A: Extracellular vesicles produced by Cryptococcus neoformans contain protein components associated with virulence. Eukaryot Cell 2008, 7(1):58-67.

80. Kubitschek-Barreira PH, Curty N, Neves GW, Gil C, Lopes-Bezerra LM: Differential proteomic analysis of Aspergillus fumigatus morphotypes reveals putative drug targets. J Proteomics 2013, 78:522-534.

81. Previato JO, Gorin PAJ, Travassos LR: Cell-wall composition in different cell-types of the dimorphic species sporothrix-schenckii. Exp Mycol 1979, 3(1):83-91.

82. Previato JO, Gorin PAJ, Haskins RH, Travassos LR: Soluble and insoluble glucans from different cell types of the human pathogen Sporothrix schenckii. Exp Mycol 1979, 3(1):14

83. Lenardon MD, Munro CA, Gow NA: Chitin synthesis and fungal pathogenesis. Curr Opin Microbiol 2010, 13(4):416-423.

84. Nino-Vega GA, Sorais F, San-Blas G: Transcription levels of CHS5 and CHS4 genes in Paracoccidioides brasiliensis mycelial phase, respond to alterations in external osmolarity, oxidative stress and glucose concentration. Mycol Res 2009, 113(Pt 10):1091-1096.

85. Latge JP: The cell wall: a carbohydrate armour for the fungal cell. Mol Microbiol 2007, 66(2):279-290 
86. Mandel MA, Galgiani JN, Kroken S, Orbach MJ: Coccidioides posadasii contains single chitin synthase genes corresponding to classes I to VII. Fungal Genet Biol: FG \& B 2006, 43(11):775-788

87. Martin-Urdiroz M, Roncero Ml, Gonzalez-Reyes JA, Ruiz-Roldan C: ChsVb, a class VII chitin synthase involved in septation, is critical for pathogenicity in Fusarium oxysporum. Eukaryot Cell 2008, 7(1):112-121.

88. Takeshita N, Yamashita S, Ohta A, Horiuchi H: Aspergillus nidulans class V and $\mathrm{VI}$ chitin synthases CsmA and CsmB, each with a myosin motor-like domain, perform compensatory functions that are essential for hyphal tip growth. Mol Microbio/ 2006, 59(5):1380-1394.

89. Takeshita N, Ohta A, Horiuchi H: csmA, a gene encoding a class $V$ chitin synthase with a myosin motor-like domain of Aspergillus nidulans, is translated as a single polypeptide and regulated in response to osmotic conditions. Biochem Biophys Res Commun 2002, 298(1):103-109.

90. Frade-Pérez M, Hernández-Cervantes A, Flores-Carreón A, Mora-Montes HM: Biochemical characterization of Candida albicans a-glucosidase I heterologously expressed in Escherichia coli. Antonie Van Leeuwenhoek 2010, 98(3):291-298.

91. Robledo-Ortiz Cl, Flores-Carreón A, Hernández-Cervantes A, Álvarez-Vargas A, Lee KK, Díaz-Jiménez DF, Munro CA, Cano-Canchola C, Mora-Montes HM: Isolation and functional characterization of Sporothrix schenckii ROT2, the encoding gene for the endoplasmic reticulum glucosidase II. Fungal Biol 2012, 116(8):910-918.

92. Mora-Montes HM, Robledo-Ortiz Cl, González-Sánchez LC, López-Esparza A, López-Romero E, Flores-Carreón A: Purification and biochemical characterisation of endoplasmic reticulum a1,2-mannosidase from Sporothrix schenckii. Mem Inst Oswaldo Cruz 2010, 105(1):79-85.

93. Lee J, Park S-H, Stanley P: Antibodies that recognize bisected complex $\mathrm{N}$-glycans on cell surface glycoproteins can be made in mice lacking $\mathrm{N}$-acetylglucosaminyltransferase III. Glycoconj J 2002, 19(3):211-219.

94. Nakamura Y: Purification and isolation of a biologically active peptido-rhamnogalactan from Sporothrix schenckii. J Dermatol 1976, 3(1):25-29.

95. El-Ganiny AM, Sanders DAR, Kaminskyj SGW: Aspergillus nidulans UDP-galactopyranose mutase, encoded by ugmA plays key roles in colony growth, hyphal morphogensis, and conidiation. Fungal Genet Biol 2008, 45(12):1533-1542.

96. Alviano CS, Pereira MEA, Souza W, Oda LM, Travassos LR: Sialic acids are surface components of Sporothrix schenckii yeast forms. FEMS Microbiol Lett 1982, 15(3):223-228.

97. Lopes-Alves LM, Mendonca-Previato L, Fournet B, Degand P, Previato JO: O-glycosidically linked oligosaccharides from peptidorhamnomannans of Sporothrix schenckii. Glycoconj J 1992, 9(2):75-81.

98. Madduri K, Waldron C, Merlo DJ: Rhamnose biosynthesis pathway supplies precursors for primary and secondary metabolism in Saccharopolyspora spinosa. J Bacteriol 2001, 183(19):5632-5638.

99. Watt G, Leoff C, Harper AD, Bar-Peled M: A bifunctional 3,5-epimerase/4-keto reductase for nucleotide-rhamnose synthesis in Arabidopsis. Plant Physiol 2004, 134(4):1337-1346.

100. Martinez V, Ingwers M, Smith J, Glushka J, Yang T, Bar-Peled M: Biosynthesis of UDP-4-keto-6-deoxyglucose and UDP-rhamnose in pathogenic fungi Magnaporthe grisea and Botryotinia fuckeliana. J Biol Chem 2011 287(2):879-892

101. Plonka PM, Grabacka M: Melanin synthesis in microorganismsbiotechnological and medical aspects. Acta Biochim Pol 2006, 53(3):429-443.

102. Eisenman HC, Casadevall A: Synthesis and assembly of fungal melanin. Appl Microbiol Biotechnol 2012, 93(3):931-940.

103. Almeida-Paes R, Frases S, Araujo Gde S, de Oliveira MM, Gerfen GJ Nosanchuk JD, Zancope-Oliveira RM: Biosynthesis and functions of a melanoid pigment produced by species of the sporothrix complex in the presence of L-tyrosine. Appl Environ Microbiol 2012, 78(24):8623-8630.

104. Almeida-Paes R, Frases S, Fialho Monteiro PC, Gutierrez-Galhardo MC, Zancope-Oliveira RM, Nosanchuk JD: Growth conditions influence melanization of Brazilian clinical Sporothrix schenckii isolates. Microb Infect/Institut Pasteur 2009, 11(5):554-562.

105. Nosanchuk JD, Casadevall A: Impact of melanin on microbial virulence and clinical resistance to antimicrobial compounds. Antimicrob Agents Chemother 2006, 50(11):3519-3528.

106. Fernandes KS, Coelho AL, Lopes Bezerra LM, Barja-Fidalgo C: Virulence of Sporothrix schenckii conidia and yeast cells, and their susceptibility to nitric oxide. Immunology 2000, 101(4):563-569.
107. Darling AC, Mau B, Blattner FR, Perna NT: Mauve: multiple alignment of conserved genomic sequence with rearrangements. Genome Res 2004 14(7):1394-1403

108. Korf I: Gene finding in novel genomes. BMC Bioinformatics 2004, 5:59.

109. Stanke M, Waack S: Gene prediction with a hidden Markov model and a new intron submodel. Bioinformatics 2003, 19(Suppl 2):ii215-ii225.

110. Slater GS, Birney E: Automated generation of heuristics for biological sequence comparison. BMC Bioinformatics 2005, 6:31.

111. Haas BJ, Salzberg SL, Zhu W, Pertea M, Allen JE, Orvis J, White O, Buell CR, Wortman JR: Automated eukaryotic gene structure annotation using EVidenceModeler and the Program to Assemble Spliced Alignments. Genome Biol 2008, 9(1):R7.

112. Almeida LG, Paixao R, Souza RC, Costa GC, Barrientos FJ, Santos MT, Almeida DF, Vasconcelos AT: A System for Automated Bacterial (genome) Integrated Annotation-SABIA. Bioinformatics 2004, 20(16):2832-2833.

113. Jurka J, Kapitonov W, Pavlicek A, Klonowski P, Kohany O, Walichiewicz J: Repbase update, a database of eukaryotic repetitive elements. Cytogenet Genome Res 2005, 110(1-4):462-467.

114. Wheeler TJ, Clements J, Eddy SR, Hubley R, Jones TA, Jurka J, Smit AF, Finn RD: Dfam: a database of repetitive DNA based on profile hidden Markov models. Nucleic Acids Res 2013, 41(Database issue):D70-D82.

115. Llorens C, Futami R, Covelli L, Dominguez-Escriba L, Viu JM, Tamarit D, Aguilar-Rodriguez J, Vicente-Ripolles M, Fuster G, Bernet GP, Maumus F, Munoz-Pomer A, Sempere JM, Latorre A, Moya A: The Gypsy Database (GyDB) of mobile genetic elements: release 2.0. Nucleic Acids Res 2011, 39(Database issue):D70-D74.

116. Marchler-Bauer A, Lu S, Anderson JB, Chitsaz F, Derbyshire MK, DeWeese-Scott C, Fong JH, Geer LY, Geer RC, Gonzales NR, Gwadz M, Hurwitz DI, Jackson JD, Ke Z, Lanczycki CJ, Lu F, Marchler GH, Mullokandov M, Omelchenko MV, Robertson CL, Song JS, Thanki N, Yamashita RA, Zhang D, Zhang N, Zheng C, Bryant SH: CDD: a conserved domain database for the functional annotation of proteins. Nucleic Acids Res 2011, 39(Database issue):D225-D229.

117. Benson G: Tandem repeats finder: a program to analyze DNA sequences. Nucleic Acids Res 1999, 27(2):573-580.

118. Wicker T, Sabot F, Hua-Van A, Bennetzen JL, Capy P, Chalhoub B, Flavell A, Leroy $P$, Morgante M, Panaud O, Paux E, SanMiguel P, Schulman AH: A unified classification system for eukaryotic transposable elements. Nat Rev Genet 2007, 8(12):973-982.

119. Rutherford K, Parkhill J, Crook J, Horsnell T, Rice P, Rajandream MA, Barrell B: Artemis: sequence visualization and annotation. Bioinformatics 2000, 16(10):944-945.

120. Cantarel BL, Coutinho PM, Rancurel C, Bernard T, Lombard V, Henrissat B: The Carbohydrate-Active EnZymes database (CAZy): an expert resource for glycogenomics. Nucleic Acids Res 2009, 37(Database issue):D233-D238.

121. Altschul SF, Gish W, Miller W, Myers EW, Lipman DJ: Basic local alignment search tool. J Mol Biol 1990, 215(3):403-410

122. Eddy SR: Profile hidden Markov models. Bioinformatics 1998, 14(9):755-763.

123. Apweiler R, Attwood TK, Bairoch A, Bateman A, Birney E, Biswas M, Bucher P, Cerutti L, Corpet F, Croning MD, Durbin R, Falquet L, Fleischmann W, Gouzy J, Hermjakob H, Hulo N, Jonassen I, Kahn D, Kanapin A, Karavidopoulou Y, Lopez R, Marx B, Mulder NJ, Oinn TM, Pagni M, Servant F, Sigrist CJ, Zdobnov EM: The InterPro database, an integrated documentation resource for protein families, domains and functional sites. Nucleic Acids Res 2001, 29(1):37-40.

124. Sonnhammer EL, Eddy SR, Durbin R: Pfam: a comprehensive database of protein domain families based on seed alignments. Proteins 1997 28(3):405-420

125. Schultz J, Milpetz F, Bork P, Ponting CP: SMART, a simple modular architecture research tool: identification of signaling domains. Proc Natl Acad Sci U S A 1998, 95(11):5857-5864.

126. Storey JD, Tibshirani R: Statistical significance for genome-wide studies. Proc Natl Acad Sci 2003, 100:9440-9445.

127. Storey JD, Tibshirani R: Statistical significance for genomewide studies. Proc Natl Acad Sci U S A 2003, 100(16):9440-9445.

128. Thompson JD, Higgins DG, Gibson TJ: CLUSTAL W: improving the sensitivity of progressive multiple sequence alignment through sequence weighting position-specific gap penalties and weight matrix choice. Nucleic Acids Res 1994, 22(22):4673-4680.

129. Capella-Gutierrez S, Silla-Martinez JM, Gabaldon T: trimAl: a tool for automated alignment trimming in large-scale phylogenetic analyses. Bioinformatics 2009, 25(15):1972-1973. 
130. Abascal F, Zardoya R, Posada D: ProtTest: selection of best-fit models of protein evolution. Bioinformatics 2005, 21(9):2104-2105.

131. Guindon S, Delsuc F, Dufayard JF, Gascuel O: Estimating maximum likelihood phylogenies with PhyML. Methods Mol Biol 2009, 537:113-137.

132. Durand D, Halldorsson BV, Vernot B: A hybrid micro-macroevolutionary approach to gene tree reconstruction. J Comput Biol: I Comput Mol Cell Biol 2006, 13(2):320-335.

133. Katoh K, Misawa K, Kuma K, Miyata T: MAFFT: a novel method for rapid multiple sequence alignment based on fast Fourier transform. Nucleic Acids Res 2002, 30(14):3059-3066.

134. Stamatakis A, Ludwig T, Meier H: RAxML-III: a fast program for maximum likelihood-based inference of large phylogenetic trees. Bioinformatics 2005, 21(4):456-463.

135. Sanderson MJ: r8s: inferring absolute rates of molecular evolution and divergence times in the absence of a molecular clock. Bioinformatics 2003, 19(2):301-302.

136. Taylor JW, Berbee ML: Dating divergences in the Fungal Tree of Life: review and new analyses. Mycologia 2006, 98(6):838-849.

137. Lucking R, Huhndorf S, Pfister DH, Plata ER, Lumbsch HT: Fungi evolved right on track. Mycologia 2009, 101(6):810-822.

138. de Groot PW, Brandt BW: ProFASTA: a pipeline web server for fungal protein scanning with integration of cell surface prediction software. Fungal Genet Biol 2012, 49(2):173-179.

139. Chaudhuri R, Ansari FA, Raghunandanan MV, Ramachandran S: FungalRV: adhesin prediction and immunoinformatics portal for human fungal pathogens. BMC Genomics 2011, 12:192

140. Eisenhaber B, Schneider G, Wildpaner M, Eisenhaber F: A sensitive predictor for potential GPI lipid modification sites in fungal protein sequences and its application to genome-wide studies for Aspergillus nidulans, Candida albicans, Neurospora crassa, Saccharomyces cerevisiae and Schizosaccharomyces pombe. J Mol Biol 2004, 337(2):243-253.

141. Suzuki K, Ohsumi Y: Molecular machinery of autophagosome formation in yeast, Saccharomyces cerevisiae. FEBS Lett 2007, 581(11):2156-2161.

142. Weinberg J, Drubin DG: Clathrin-mediated endocytosis in budding yeast. Trends Cell Biol 2012, 22(1):1-13.

doi:10.1186/1471-2164-15-943

Cite this article as: Teixeira et al:: Comparative genomics of the major fungal agents of human and animal Sporotrichosis: Sporothrix schenckil and Sporothrix brasiliensis. BMC Genomics 2014 15:943.

\section{Submit your next manuscript to BioMed Central and take full advantage of:}

- Convenient online submission

- Thorough peer review

- No space constraints or color figure charges

- Immediate publication on acceptance

- Inclusion in PubMed, CAS, Scopus and Google Scholar

- Research which is freely available for redistribution 